\title{
THE APOSTLES' CREED (SYMBOLUM APOSTOLORUM) IN THE CHURCH SLAVONIC TRANSLATION BY Dm. GERASIMOV. INTRODUCTION. INTERLINEAR EDITION
}

\author{
Vittorio S. Tomelleri \\ Macerata State University, Macerata, Italy
}

\begin{abstract}
In the present paper the Church Slavonic translation of the Latin Apostles' Creed with commentary, made by the famous Novgorodian translator Dmitriy Gerasimov in the first half of the 16th century, is published for the first time. The text is based on all ten known manuscripts of Bruno's commented Psalter, within which the Apostles' Creed is included.

The Slavonic translation consists of four parts: 1) a short introduction, where the different meanings of the term "Simvol" are explained; 2) a note on the Creeds used in the Christian Church, namely the Apostles' Creed, the Nicene-Constantinopolitan Creed and the Athanasian Creed, to which the mysterious Symbolum iuris is added; 3 ) the text of the Apostles' Creed and 4) the question-and-answer commentary on it. The first and second parts, going back to Latin medieval lexicographical works (Catholicon and Vocabolarius iuris utriusque), testify to the translation technique adopted by Dm. Gerasimov, who used to explain hard-to-translate terms with lexical commentaries, taken from Latin sources.

The Slavonic translation and the Latin original are given interlinearly. The edition is preceeded by an introduction, in which some information about the complicated transmission of the Latin text is provided, the different sources used by the translator are discussed and, finally, some textual and linguistic features of the Slavonic text are shortly described.

Key words: Apostles' Creed, Latin tradition, Church Slavonic translation, Dmitry Gerasimov, Bruno of Würzburg.

Citation. Tomelleri V.S. The Apostles' Creed (Symbolum Apostolorum) in the Church Slavonic Translation by Dm. Gerasimov. Introduction. Interlinear Edition. Vestnik Volgogradskogo gosudarstvennogo universiteta. Seriya 2, Yazykoznanie [Science journal of Volgograd State University. Linguistics], 2017, vol. 16, no. 4, pp. 6-40. (in Russian). DOI: https://doi.org/10.15688/jvolsu2.2017.4.1
\end{abstract}

УДК 81’255:27-282.3

ББК 81.18

Дата поступления статьи: 29.08.2017 Дата принятия статьи: 27.10.2017

\section{АПОСТОЛЬСКИЙ СИМВОЛ ВЕРЫ (SYMВОLUM APOSTOLORUM) В ЦЕРКОВНОСЛАВЯНСКОМ ПЕРЕВОДЕ ДМ. ГЕРАСИМОВА. ВВЕДЕНИЕ. ИНТЕРЛИНЕАРНОЕ ИЗДАНИЕ}

\author{
Витторио С. Томеллери \\ Государственный университет г. Мачерата, Италия
}

Аннотация. В настоящей статье впервые издается церковнославянский перевод латинского Апостольского символа веры с толкованиями, осуществленный известным новгородским переводчиком Дмитрием Герасимовым в первой половине XVI века. Текст издается по всем десяти известным спискам церковнославянского перевода Толковой Псалтири Брунона, в состав которой входит Апостольский символ веры; под переводом приводится параллельный латинский оригинал. 
Славянский перевод состоит из четырех частей: 1) краткое введение, в котором объясняются разные значения термина «символ»; 2) заметка о четырех символах веры, используемых в Христианской церкви: Апостольский символ, Никео-Константинопольский символ, Афанасьевский символ и загадочный Symbolum iuris; 3) текст Апостольского символа; 4) толкования к нему в вопросно-ответной форме. Первая и вторая части, восходящие к латинским средневековым лексикографическим сочинениям (Catholicon и Vocabolarius iuris utriusque), свидетельствуют о способе работы Дмитрия Герасимова, снабжавшего трудно переводимые слова комментариями лексического характера, взятыми из латинских источников.

Издательскую часть предваряет вступление, в котором даются сведения о сложной традиции латинского текста, обсуждается вопрос о разных источниках, использованных переводчиком, и кратко описываются некоторые текстологические и лингвистические особенности славянского текста.

Ключевые слова: Апостольский символ веры, латинская традиция, церковнославянский перевод, Дмитрий Герасимов, Бруно Вюрцбургский.

Цитирование. Томеллери В. С. Апостольский символ веры (Symbolum Apostolorum) в церковнославянском переводе Дм. Герасимова. Введение. Интерлинеарное издание // Вестник Волгоградского государственного университета. Серия 2, Языкознание. - 2017. - Т. 16, № 4. - C. 6-40. - DOI: https://doi.org/10.15688/ jvolsu2.2017.4.1

Articuli [в тексте ош. articula] fidei sunt bis sex corde tenendi,

Quos Christi socii docuerunt Pneumate pleni:

Credo Deum Patrem, Petrus inquit, cuncta creantem;

Andreas dixit, Ego credo Jesum fore Christum;

Conceptum, natum, Jacobus; passumque Johannes; Inferna, Philippus, fregit [в тексте ош. fugit]; Thomasque, revixit;

Scandit, Bartholomaeus; veniet censere, Matthaeus; Pneuma, Minor Jacobus; Simon, peccata remittit; Restituit, Judas, carnem; vitamque, Matthias ${ }^{1}$.

\section{1. Общие замечания}

Во всех полных списках церковнославянского перевода толковой Псалтири Брунона, епископа Вюрцбургского [Tomelleri, 2004, S. 88-91], так же, как и в латинском оригинале, вслед за псалмами и библейскими песнями с толкованиями следует ряд вероисповедных текстов и молитв:

1) молитва господня (Oratio dominica) с вопросно-ответными толкованиями,

2) издаваемый здесь Апостольский символ веры (Symbolum Apostolorum), также с вопросно-ответными толкованиями ${ }^{2}$,

3) гимн «Тебе Бога хвалим» (Te Deum) и

4) Символ веры (Quicumque vult salvus esse), ложно приписанный Афанасию Александрийскому ${ }^{3}$, с толкованиями [Томеллери, 2017].

В западном Средневековье эти тексты составляли корпус сочинений, необходимых для катехетической деятельности [Kelly, 1972, p. 423; Wiegand, 1904, S. 10] ${ }^{4}$, и именно как катехет Бруно вошел в историю западной Церкви [Baier, 1893; Scheele, 1990]. Действительно, стиль Брунонова толкования, дословно повторяющего комментарий Алкуина [Probst, 1886, S. 88-89; Wiegand, 1904, S. 14$]^{5}$, характеризуется как монастырско-катехетический [Evans, 1979, p. 465] ${ }^{6}$ : богословское содержание излагается в очень простой диалогической форме (о применении диалога в катехетической практике см. [Probst, 1886, S. 70-71]). Вопросы о вере задает ученик (discipulus), как будто он справляется со сложными догматическими понятиями или же, наоборот, затрудняется при интерпретации содержания текста [Wiegand, 1904, S. 7-8 [7. Учитель (magister) отвечает на заданные вопросы в повествовательной форме [Evans, 1979, p. 466-467; см. также Specht, 1885 , S. 85].

Церковнославянский перевод, возникший под пером Дм. Герасимова в первой половине XVI в., своеобразен во многих отношениях. С одной стороны, Апостольский символ веры, как известно, малоупотребителен у восточной православной Церкви ${ }^{8}$; с другой стороны, наличие толкования делает его уникальным на православной и вообще славянской почве. Более ранний вариант текста (но без толкований) засвидетельствован лишь в средневековой хорватской глаголической традиции; перевод, также сделанный с латыни, с большой долей вероятности восходит к докирилломефодиевскому времени [Mathiesen, 1981-1984-1985].

1.1. Возникнув на юге Франции в V в. [Kelly, 1972, p. 413; Sanday, 1899, p. 6], латинский текст Апостольского символа веры, считающийся самым кратким и четким выражением христианского мировоззрения ${ }^{9}$, 
принял окончательную форму в каролингское время, в начале VIII в. или позже [Evans, 1979, p. 463-464; Pelikan, Hotchkiss, 2003, p. 667; Westra, 2002, p. 68 ${ }^{10}$; получив одобрение со стороны короля Карла Великого, боровшегося за введение общей литургической практики в западной Церкви [Westra, 2002, p. 21], затем по повелению короля Оттона I Великого текст был включен в крестильный обряд, с которым был тесно связан с самого начала своего существования [Ashwin-Siejkowski, 2009, p. 7-8; Evans, 1979, p. 464; Sanday, 1899, p. 9] ${ }^{11}$.

В своем теперешнем виде, с упоминанием 12 апостолов, текст впервые приводится в кратком пастырско-практическом катехизисе св. Пирмина (ум. в 753 г.), известном в литературе под странным названием Scarapsus ${ }^{12}$ [Denzinger, 2009, S. 38], в десятой главе первой части [Pirmin, 2010, p. 30-33, то же в: Hauswald, 2006, S. 30-33, надежнее чем в: Jecker, 1927, S. 41] ${ }^{13}$.

C конца IV в. текст стал называться «Апостольским»; по рассказу Руфина Аквилейского (Commentarius in symbolum apostolorum или Expositio symboli apostolorum), его создали сами апостолы после сошествия на них Св. Духа в день Пятидесятницы; прежде чем разойтись и начать свою проповедническую деятельность, они договорились о содержании вероисповедания:

«Discessuri itaque ab inuicem, normam prius futurae sibi praedicationis in commune constituunt, ne forte alius alio abducti, diuersum aliquid his qui ad fidem Christi inuitabantur, exponerent. Omnes igitur in uno positi et Spiritu Sancto repleti, breue istud futurae sibi, ut diximus, praedicationis indicium, conferendo in unum quod sentiebat unusquisque, conponunt, atque hanc credentibus dandam esse regulam statuunt» [Tyranni Rufini, 1961, p. 134] ${ }^{14}$.

«When they were on the point of taking leave of each other, they first settled on a common form for their future preaching, so that they might not find themselves, widely dispersed as they would be, delivering divergent messages to the people they were persuading to believe in Christ. So they all assembled in one spot and, being filled with the Holy Spirit, drafted this short summary, as I have explained, of their future preaching, each contributing the $\|$ clause he judged fitting: and they decreed that it should be handed out as standard teaching to converts» [Rufinus, 1955, p. 29-30]; немецкий перевод см. в: [Vinzent, 2006, S. 25-26].
Таким образом, до разоблачения легенды итальянским гуманистом Лоренцо Валлой около середины XV в. [Riedl, 2004, S. 52; подробнее: Dörholt, 1898, S. 18-21 и Vinzent, 2006, S. 31-32] ${ }^{15}$ возникновение текста относили к далеким апостольским временам, когда Христианство еще не находилось под угрозой еретических учений и расколов [Cullmann, 1949, S. 6; Evans, 1979, p. 470].

Свидетельство Руфина о том, что каждый апостол внес свой вклад в создание текста [Brady, 1957, p. 323; Bühler, 1953, p. 335, то же в: Bühler, 1973, p. 485; Wiegand, 1899, S. 41-42], повлияло на дальнейшую разработку мотива о творческом сотрудничестве учеников Исуса Христа [Mâle, 1995, p. 247-248]. Многие толкователи приписывали каждый стих одному из апостолов, причем у разных авторов обнаруживается большое разнообразие в их распределении (подробнее об этом см.: [Bühler, 1953; Gordon, 1965, p. 638-640]). В латинской традиции имена апостолов размещены в разном порядке (таблица, показывающая 15 различающихся между собой традиций расположения имен апостолов, приводится в: [Bühler, 1953, p. 336-337, то же в: Bühler, 1973, p. 486-487]). Например, в апокрифическом слове св. Августина обнаруживается такой порядок:

1) Petrus, 2) Andreas, 3) Jacobus (maior), 4) Joannes, 5) Thomas, 6) Jacobus (minor), 7) Philippus, 8) Bartholomaeus, 9) Matthaeus, 10) Simon, 11) Thaddaeus, 12) Matthias (Sermo 240 - Quid quisque apostolus de Symbolo composuit, Patrologia Latina, tomus XXXIX, col. 2189, цит. по [Mâle, 1995, p. 247, прим. 2]); отклонения в Sermo 241 (De symbolo) того же псевдоавтора см.: [Burn, 1899, p. 183; Dörholt, 1898, S. 11-12, прим. 3].

Первоначальное значение термина «символ», ставшего жанровым определением исповедания веры [Westra, 2010b, p. 115], довольно загадочно: ни одно из предложенных объяснений греческого заимствования symbolum ${ }^{16}$ не является удовлетворительным (обзор интерпретаций в: [Westra, 2010a]; по мнению исследователя, это слово со значением «разрешение», «пропуск», в IV и V вв. относилось исключительно к Апостольскому символу во всех его разновидностях [Westra, 2010b, p. 117]). Так как термин стал названием «Символа веры» на западноевропейском, то 
есть латиноязычном пространстве, разнообразная семантика греческого слова, подробно изученная в монографии В. Мюри [Müri, 1931] и в работе Т. Суто [Suto, 2012, p. 45-58], не является релевантной для решения проблемы $\left[\right.$ Carpenter, 1942, p. 5] ${ }^{17}$.

Здесь нет необходимости прослеживать историю возникновения и развития латинского текста Апостольского символа веры и его отношений с греческой версией ${ }^{18}$, поскольку текст в Московской Руси появился в «готовом», позднесредневековом виде, как он представлен в печатных изданиях Псалтири Брунона конца XV века. Мы ставим себе более скромную задачу, заключающуюся лишь в параллельном издании обоих текстов с учетом всех известных списков церковнославянского перевода.

1.2. Церковнославянский текст Апостольского символа веры с толкованиями состоит из четырех частей:

1) краткое введение, содержащее сведения о слове греческого происхождения символ и об апостолах;

2) заметка о четырех символах веры;

3) текст Апостольского символа веры, разбитый на 12 предложений, каждое из которых приписывается одному из апостолов;

4) толкования к Апостольскому символу веры в вопросно-ответной форме.

Только четвертая часть входит в состав латинской версии Толковой Псалтири Брунона, тогда как остальные, вводящие читателя в предмет, восходят к другим латинским источникам.

1.2.1. И.А. Подтергера выявила латинский подлинник краткого введения (первой части): речь идет о «Католиконе», всеобщей энциклопедии латинского языка [Podtergera, 2016]. Это лексико-грамматическое сочинение, написанное генуэзским монахом Джованни Бальби в конце XIII в. [Goetz, 1903, S. 152154], пользовалось большой популярностью после изобретения книгопечатания и издавалось неоднократно [Powitz, 1988]. В нем латинская лексема symbolum определяется как «собрание многих слов» (лат. collectio), а сам термин предполагает четыре вида собрания:

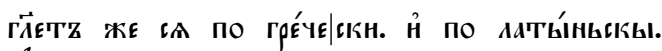
снмЕОА

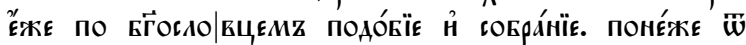

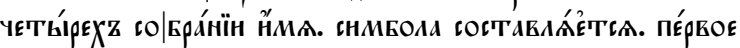

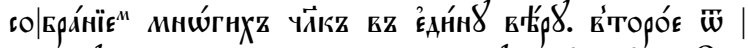

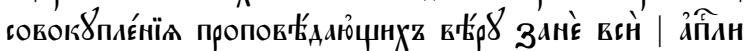

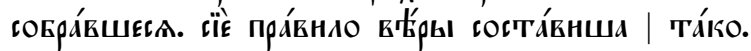

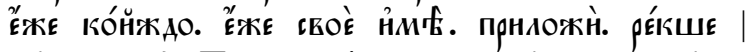

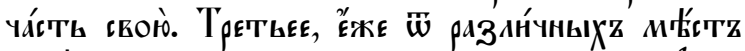

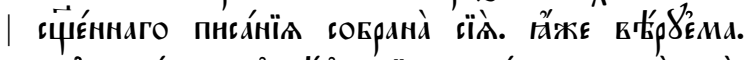

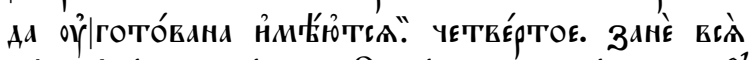

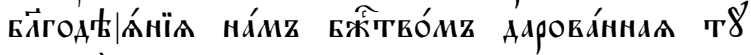
говрана̀. ।

Symbolum est collectio sermonum. ut in consilio ${ }^{19}$. [...] secundum theologum ${ }^{20}$ nomen symboli similitudinem et collectionem importat unde a quat-(t)uor collectionibus nomen symboli imponitur. Primo a collectione multorum hominum in unam fidem. Secundo a collectione praedicantium fidem. quia omnes apostoli collecti hanc regulam fidei ediderunt. ita quod unusquisque quod suum erat apposuit. [...]. Tertio quia ex diversis locis sacrae scripturae colliguntur ea quae credenda sunt. ut in promptu habeantur. Quarto quia omnia beneficia nobis divinitus collata ibi colliguntur ${ }^{21}$.

Есть основания предполагать, что подобное объяснение термина обусловлено

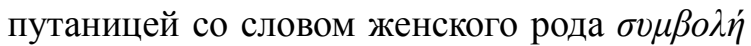
(collatio) в значении «совместная работа» [Schaff, 1877, p. 3, прим. 3; Schlesinger, 1912, S. 20] ${ }^{22}$ и, по сути дела, влиянием предания о предполагаемом создании Символа веры апостолами [Connolly, 1946, p. 187], как явствует из комментария выше упомянутого Руфина:

«Symbolum Graece et indicium dici potest et collatio, hoc est quod plures in unum conferunt» [Hitchkock, 1946, p. 62] - «Symbol in Greek can mean both 'token' and 'collection', that is, a joint whole to which several persons contribute» [Rufinus, 1955, p. 30; см. также примечания издателя на с. 101-102].

Глоссаторско-компилятивный характер «Католикона» подтверждается еще и тем отнюдь немаловажным фактом, что целый пассаж из «Католикона» дословно повторяет комментарий Фомы Аквинского к Сентенциям Петра Ломбардского (Distinctio XXV, quaestiuncula III, solutio III):

AD TERTIAM QUAESTIONEM dicendum quod nomen symboli similitudinem et collectionem importat. Unde a quatuor collectionibus nomen symboli imponitur. Primo, a collectione multorum hominum in unam fidem. Secundo, a collectione praedicantium fidem; quia omnes Apostoli collecti hanc regulam fidei ediderunt, unusquisque quod suum est (разночтение erat. - B. C. T.) apponens. Tertio, quia 
ex diversis locis Sacrae Scripturae colliguntur ea quae credenda sunt, ut in promptu habeantur. Quarto, quia omnia beneficia nobis divinitus collata ibi colliguntur [Thomas Aquinas, 1933, p. 786] ${ }^{23}$.

В приведенном выше пассаже представлен, вероятно, первый восточнославянский перевод одного небольшого фрагмента из раннего сочинения крупного средневекового теолога; ни наличие промежуточного лексикографического звена, то есть «Католикона», ни более чем возможная неосведомленность переводчика о первоначальном авторе комментария никак не умаляют значимости этого уже самого по себе интересного текста.

1.2.2. Для заметки о символах веры (второй части) пока не удалось выявить возможные линии традиции. В этой части текста в очень сжатой форме перечисляются все символы веры: к трем традиционным текстам западной Церкви [Dörholt, 1898, S. 9], то есть Апостольскому символу [Pelikan, Hotchkiss, 2003, p. 667-669], Никео-Константинопольскому символу [Pelikan, Hotchkiss, 2003, p. 670-672] и Афанасьевскому символу [Pelikan, Hotchkiss, 2003, p. 673-677] ${ }^{24}$, выполняющим, по словам Альберта Великого, тройную функцию (дидактическую, объяснительную и оборонительную) ${ }^{25}$, в перечне прибавляется еще четвертый, касающийся высшей Троицы и соборной веры (summa Trinitas et catholica fides). Учитывая тот факт, что речь идет в основном о текстах западного происхождения или, по крайней мере, употребления, можно предположить, что и заметка о символах веры должна соотноситься с каким-то латинским источником ${ }^{26}$; в пользу этого предположения можно привести также ссылку на седьмую главу седьмой книги Этимологий Исидора Севильского.

Нам удалось найти для последней части заметки латинский текст, очень близкий, но не тождественный, церковнославянскому переводу; он встречается в Vocabularius iuris utriusque эрфуртского юриста Йодока (Iodocus Erfordensis) под леммой symbolum, начинающейся словами Symbolum est quadruplex (здесь цитата приводится по инкунабуле 1477 г., Speyer: Peter Drach der Ältere ${ }^{27}$ ):

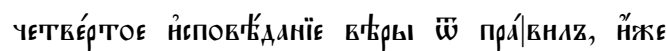

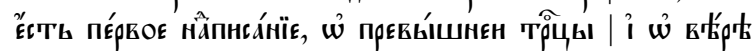

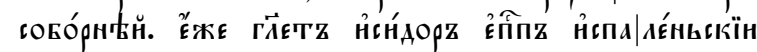

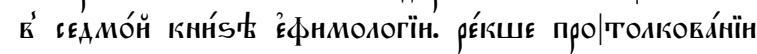

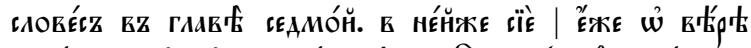

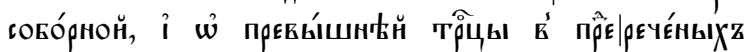

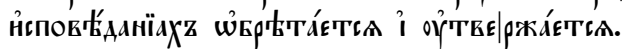

Quartum symbolum est iuris, scilicet primus titulus de summa Trinitate et fide catholica, ut ait Isidorus vii libro Etymologiarum, capite vii, in quo id quod de fide catholica et summa Trinitate in praedictis symbolis continetur, confirmatur et repetitur.

Не следует, однако, делать преждевременного вывода о прямой связи между церковнославянским переводом и этим сочинением; в распоряжении переводчика мог находиться другой источник, содержавший такого рода глоссу.

Как бы то ни было, заслуживает особого внимания прямое упоминание не только епископа Исидора, но и его главного труда, носящего название Etymologiae, для которого в славянском тексте предлагается следующее объяснительное определение: протолкова́мї̈а слове́ст. Здесь уместно упомянуть о том, что в конвое Толковой Псалтири Брунона имеется полный перевод 39-й главы, посвященной исчислению времени от сотворения мира, которая взята из 5-ой книги Этимологий Исидора [Tomelleri, 2008, S. 35-36]:

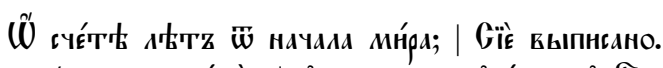

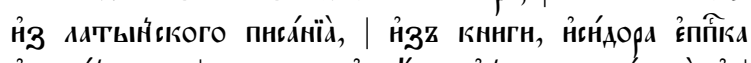

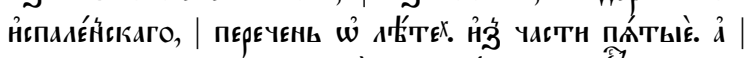

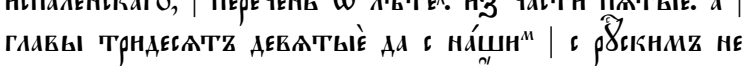

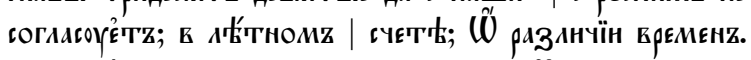
гАн

Очень интересны и ценны наблюдения И.А. Подтергеры о разнообразной передаче «латинского» слова symbolum во введении (часть первая) и в заметке (часть вторая): если в заглавии введения переводчик употребляет более нейтральное и понятное для славянского (православного) читателя название «Исповедание православной веры», то далее он, согласно латинскому произношению, в самом тексте выбирает графический вариант с буквой $b$, тогда как в заметке о символах слово обнаруживает грекообразный вид [Podtergera, 2016]. Трудно, однако, осмыслить начальные слова введения

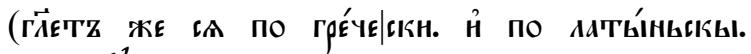
снмкол 8 мz), не имеющие точного соответствия в латинском тексте. Может быть, этими словами Дм. Герасимов пытался объяснить то, что латинское слово symbolum представляет собой греческое заимствование. Следовательно, 
Апостольский символ веры (Symbolum Apostolorum) в церковнославянском переводе Дм. Герасимова

нельзя исключать того, что здесь пропущено

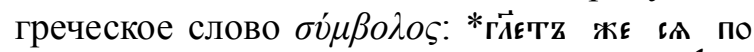

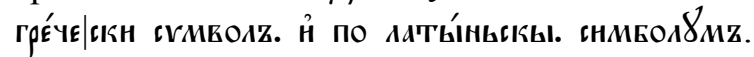

1.2.3. Как мы уже упоминали, в третьей части, также лишь частично связанной с латинской традицией Бруноновской Псалтири, представлен славянский текст Апостольского символа веры, причем разбивка на стихи соответствует такому порядку расположения имен апостолов (см. таблицу), который не совпадает ни с одним из пятнадцати типов, выявленных Бюлером при сравнении разных традиций.

1.3. В основу издания церковнославянского перевода Апостольского символа веры положена рукопись, хранящаяся в Библиотеке Академии Наук (сокр. В), с исправлением неверных чтений и с восполнением пропусков по другим спискам, среди которых лучшим и более точным является Sol, древнейший полный список Толковой Псалтири Брунона.

Латинский текст воспроизводится по 142 тому латинской патрологии [Denzinger, 1880, col. 559-561] с учетом печатного издания Антона Кобергера 1494 г. [Proctor, 1960, p. 140; Universitätsbibliothek Wien, 1996, S. 28] ${ }^{29}$, заканчивающегося следующим колофоном:

Beati Brunonis psalterium ex doctorum dictis collectum per Antonium Koberger impressum:
Anno incarnate deitatis millesimo quadringentesimo nonagesimo quarto finit feliciter (http://reader.digitalesammlungen.de/resolve/display/bsb11303153.html, 14.08.2017).

В отличие от предыдущих изданий Expositio Psalmorum Брунона, изготовленных в мастерской немецкого печатника Георга Рейзера (1485, 1489), Кобергер выбрал рамочное построение текста, при котором толкования, написанные более мелким шрифтом, окружают основной текст, положенный в средней части разворота (см. рисунок) ${ }^{30}$.

Те места латинского текста, для которых латинский оригинал пока остался неизвестным, реконструированы на основе церковнославянского перевода и выделяются в издании жирным шрифтом.

Латинский текст Апостольского символа веры разбит на 12 стихов, каждый из которых снабжен буквой латинского алфавита (a, b, c, $\mathrm{d}, \mathrm{e}, \mathrm{f}, \mathrm{g}, \mathrm{h}, \mathrm{i}, \mathrm{k}, \mathrm{l}, \mathrm{m})$, отсылающей к соответствующему месту в комментарии.

В славянском же переводе Толковой Псалтири Брунона основной текст и толкования к нему чередуются, причем первый обычно написан киноварью; на полях расположены кириллические буквы, которые употребляются не в числовом значении, а даны в подражание

\section{Порядок следования стихов в соотношении с именами апостолов}

\begin{tabular}{|c|l|l|}
\hline Стих & \multicolumn{1}{|c|}{ Содержание } & \multicolumn{1}{c|}{ Апостол } \\
\hline 1 & Бог Отец & Петр \\
\hline 2 & Исус Христос & Иоанн (сын Зеведея) \\
\hline 3 & Зачатие и рождение & Иаков старший \\
\hline 4 & Распятие и смерть & Андрей \\
\hline 5 & Сошествие в ад и воскресение & Фома \\
\hline 6 & Восхождение на небо & Варфоломей \\
\hline 7 & Страшный суд & Филипп \\
\hline $8^{*}$ & Святой Дух & Матфей \\
\hline 9 & Святая Церковь & Иаков младший \\
\hline 10 & Отпущение грехов & Симон Кананит \\
\hline 11 & Воскресение плоти & Иуда Фаддей \\
\hline 12 & Вечная жизнь & Матфей ${ }^{* *}$ \\
\hline
\end{tabular}

* В немецком переводе Апостольского символа веры восьмой и девятый стихи соединены, поэтому общее число доходит до 11 [Baier, 1893, S. 124, прим.*]). Кроме того, Брунон не упоминает предания о создании текста апостолами [Evans, 1979, p. 471]; то, что приводится в третьей части введения, следовательно, также восходит к другому источнику.

** Матфей занимает место Иуды Искариота [Gordon, 1965, p. 634]. 


\section{(Ozatiodilica.}

tus eft. đ̇ tí glozia magts ofcif́ ifrl'. cuit biu iperá $\tau$ ex quo pnüctatus aduenit. \$entiú to reuelatio quagvifitare $z$ illuftrare parit

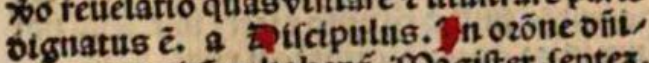
ca quot peritốes babent . LDägifter. feptes. 0 que eft patms. 2D sanctificet nomẽ tuuz. 0 boc gỏ in capite Pater nú ḋ es in celis Quó intellígitur. $2 \mathrm{D}$ Sbi eif inuocatio or gnitatis eft outu piem nos bie pfiteluur beil. quia omines fratres fin nus. $i$ oeil piem babe mus in celis.

b 0 In prima peti. tó quâ oixtift quíd in telligendí eft. 20 xp̉o eî́ xṕtanus oert,

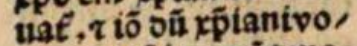
çmur:xp̂i inomé tene, mus , $\tau$ iupplicamus. vt opa $x \bar{p} t$ facere valea ทuษ. $r$ noiné fuú p ope raboina nra: in nobis fanctificet.

c $)$ Que feciuda pe titio. $2 \mathrm{D} 2$ dueniat regniu tuî. 0 Q Quid ibi intelligêda ca. 20 if zamus efivt $x \bar{p} c$ re) ghet in nobts. $z$ nó ois bolus.t.eccia xp̃ $\mathrm{i}$ fent, per crefcst.in â regnat oeus. $z$ oies iudicij ad veniat. 42 tic oiabol? regnare in mudo oefi,

nê gentiú : $\tau$ gloată plebig IQ 2 atto onilica tue ifrt. alsatb.vi. $r$ zuce.xi. efter nofter quies in celıs. Sanctificet no irten tuî. 2lduentat regniı tuĩ. Siat volútas tua ficut in celo $z$ in terra. Danem ñ̂̉m quotıdianí oa nobis f bodie. Ft oimittenob oe, bita nr̈a:ficut $\tau$ nog oimit timus oebitorub? nŕis. \&t nenos inducss in têtatio b \$\$5 libera nos a malo amé tÉtimbolin sploz.

firedo in oeum piem oipotentê : creatozes

b celiet fre. $t$ in iefum xṕm filiû́ eiug vhucû́: oím nrm. c Qui conceptus eit oe fpú fctô:natus exmariex̋gine iftit. $\tau \times \bar{p}$ c cum fanctio fuís in eternú regna bit. 00 Q que eft tercia. 20 fiat volí tas tua ficut in celo $\tau$ in terrs. $O$ Q Quō tntelligenda. $2 \mathrm{D}$ Stcut angeli in celo tue obediunt volutati. ita $r$ iufti tn terra faciả. $\tau$ ficut in fanctis.ita $\tau$ in pctóztb?tua volī, ras implent. e $\boldsymbol{O}$ Que eft quarta. 20 - oané noftrí quotıdianú oa nobis bodıe. D. Qutd in es tnteligitur. 2D boc loco panis p oibus cibis acctpté se dbus vitue, re ocbeantss: camur etiâ $p$ affumptiōe coz

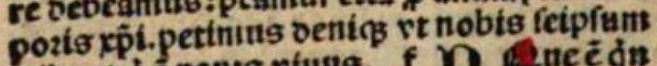

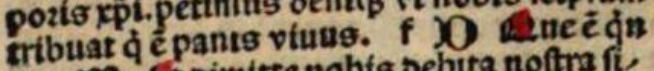
ca. $2 \mathrm{D}$ Et vimitre nobts bebita noftra fi, cit $\tau$ nos otmitrimus oebitozibus noftris. Q Quid un flls fentiendū eft, 2D 2 zeca
Duare oicif omnipotens: $\tau$ quare cre atoz. 20 D mniposens oicif. quia omnts poteft quecuncs vult. creatoz co $q$ oís creas uit:celî $z$ terram $z$ mare $z$ omnia.

b $\mathrm{X}$ gredts in biefum $x \mathrm{pm}$. ID fino credo in tefum xp̄m filití ct' vnicü orim nim out eft verus oeus $\tau$ verus bomo.

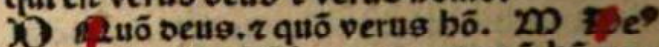
verue eft.q2 oe fpúfancto ?ceptus é. bơ ve rug. quia ex narta virgine narus eft.

c 0 Acce tllum natü. ¿d poftea factun $\varepsilon_{\text {. }}$

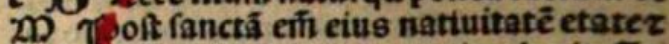
fapis crefcens triginta annos impleuit. In qua eță etate a fobanne baptifta otgnatus é baptizari. 2 poft baptifmum tribus annts z otmidio pocuit. Etapredicauit omnis que

Bruno Herbipolensis, Psalterium, Nürnberg: Anton Koberger, 1494, scan. 403 
Апостольский символ веры (Symbolum Apostolorum) в церковнославянском переводе Дм. Герасимова

латинской системе отсылки в рамочном построении.

Таким образом, церковнославянский текст Апостольского символа веры воспроизводится отдельно (третья часть), после него начинается дидактическо-катехетический «разговор» между учеником и учителем. Кириллические буквы засвидетельствованы почти исключительно в списке Sol; поскольку в нем в некоторых местах разбивка текста не соответствует латинской модели, трудно определить, следует ли видеть в них позднюю вставку переписчика или остатки первоначального текста.

Интерлинеарное издание предваряет вступление, в котором, не претендуя на полноту изложения, отмечаем некоторые интересные явления текстологического и лингвистического характера.

\section{2. Вступление}

\section{1. Текстология}

Как уже сказано, неверные чтения, ошибки и пропуски в основном списке В исправляются с учетом других списков, напр.:

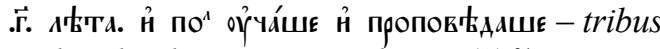
annis et dimidio docuit. Et praedicavit (3) ${ }^{31}$.

В содержит здесь явно искаженное чтение поюүуча́шє, возникшее в результате превращения лексического элемента по“ в глагольную приставку по (lectio facilior).

Ocобое положение списка Sol доказывают, кроме прочих, следующие примеры:

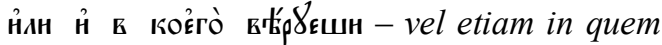
credas (1).

Во всех других списках, вследствие обычной гаплографии, соединительный союз н (для лат. etiam) отсутствует.

Самым значительным разночтением, убедительно доказывающим близость списка Sol к несохранившемуся оригиналу, является глагольная форма нзzсказахом (exposuimus) в конечном предложении текста:

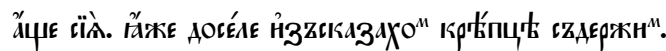

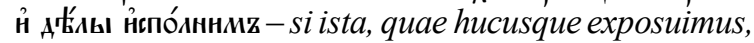
firmiter teneamus et operibus impleamus (12).

В остальных списках читаем lectio facilior нзzыскахо чтение нзыска|3ахо промежуточное звено между первоначальным чтением и его упрощенной формой.

Нельзя, однако, думать, что список Sol всегда представляет более правильные чтения. В некоторых случаях там обнаруживается вторичное (сомнительное или ошибочное) чтение, вкравшееся в текст в процессе переписывания. Например, в одном месте введения (первая часть по нашей сегментации текста) страдательное причастие настоящего времени в息馆ма, соответствующее, как правило, латинскому герундиву credenda (подробнее об этом см. [Томеллери, 2013, с. 216-219]), было заменено переписчиком списка Sol (или его антиграфа) на форму первого лица множественного числа настоящего времени изъявительного наклонения вњрУ'ємz:

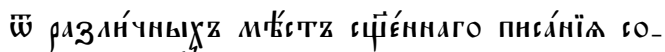

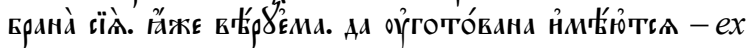
diversis locis Sacrae Scripturae colliguntur ea quae credenda sunt, ut in promptu habeantur.

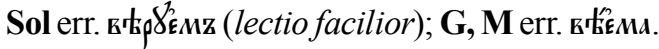

При отсутствии латинского текста, естественно, вариант Sol мог бы быть действительно оценен как более правильное и предпочтительное чтение.

Кроме этого, существуют разночтения Sol, которые не имеют однозначной интерпретации:

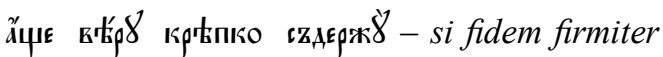
tenuero (9).

Во всех остальных списках вместо наречия крњпко читаем прилагательное крьпку, согласованное с предшествующим существительным вєр. Заманчиво считать первичной адвербиальную форму Sol, приписав переписчику антиграфа, к которому восходят другие списки, ее замену на адъективную. В толковании к последнему стиху, однако, лат. наречию firmiter соответствует во всех без исключения списках форма крғпц', так что чтение кр'ппко в Sol можно было бы оценить и как механическое искажение недописанной первоначальной формы винительного падежа кр'ппкоу.

\section{2. Переводческая техника}

Дм. Герасимов, как известно, в своих переводах всегда оставался верным латинскому оригиналу, соблюдая, например, по возможности, порядок слов оригинала [Wimmer, 1990, 
p. 53]. Это относится к глагольной морфологии и к синтаксису.

В передаче временных форм латинского оригинала складывается следующая картина соответствий:

слав. настоящее время - лат. praesens,

слав. имперфект - лат. imperfectum,

слав. аорист - лат. perfectum (л-формы употребляются исключительно для передачи отложительных глаголов лат. подлинника),

слав. настоящее время (совершенного вида) - лат. futurum I и II.

В тексте, однако, встречаются некоторые отклонения от ожидаемой картины, которые частично еще нуждаются в объяснении.

слав. имперфект-лат. participium praesentis: расти́ше - crescens (3);

слав. имперфект - лат. perfectum:

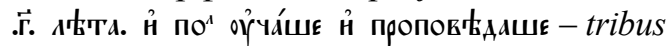
annis et dimidio docuit et praedicavit (3).

В этом месте латинский перфект переводится церковнославянским имперфектом при обозначении непредельного делимитативного действия.

слав. аорист - лат. praesens:

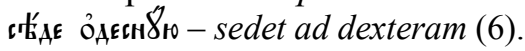

В данном случае употребление аористной формы связано с инерцией церковнославянской традиции (см., например: [Проповеди, 1901, c. 184]); как известно, замена аористной формы на перфектную привела к обвинению Максима Грека в ереси [Успенский, 2002, с. 230-233].

слав. настоящее время - лат. imperfectum: мо́жємz-poteramus (9).

Латинский перфект передается в церковнославянском переводе по-разному. Употребление формы настоящего времени в следующем примере можно считать либо переводческой ошибкой (Übersetzungsfehler) либо ошибкой в передаче текста (Überlieferungsfehler):

что творн́тв - quid fecit (5), прочтено как *facit или возникшее из * творн.

Латинские отложительные глаголы в перфекте последовательно передаются аналитическим способом соответственно латинской модели:

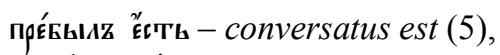

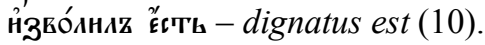

Латинские формы перфекта страдательного залога передаются тремя способами:

1) поморфемно, причастием прошедшего времени страдательного залога в сочетании со связкой:

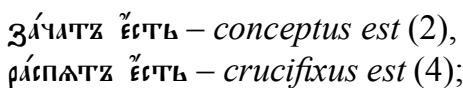

2) аористом с местоимением сА:

POAH́́s - natus est (2);

3) сочетанием причастия прошедшего времени страдательного залога с аористом глагола вытн:

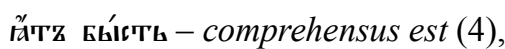
погрєБє" Биі́сть - sepultus est (4).

Необходимо при этом отметить, что и в латинском тексте засвидетельствована аналитическая форма с вспомогательным глаголом esse в перфекте, которая, однако, переводится формой настоящего времени глагола Бытн:

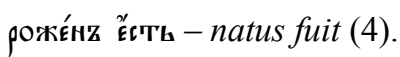

Особняком стоит лексикализованное соответствие:

Би́ість - factum est $(2,4)$.

При передаче активного описательного спряжения (periphrastica activa) релевантным становится видовое противопоставление, так как используется либо составная форма несовершенного вида, либо простая форма совершенного вида:

творнітн к 8 АєТт - facturus erit? (7),

прї́ндетz - venturus est (7).

В конструкции винительного с инфинитивом (см. ниже) подобные формы могли передаваться, естественно, только неопределенной формой соответствующего глагола:

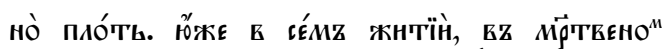

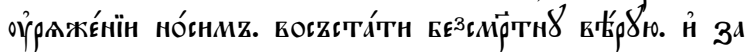

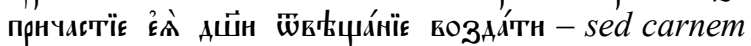
quam in hac vita sub mortali conditione portamus, resurrecturam esse immortalem credo, et pro consortio eius animam rationem reddituram (11),

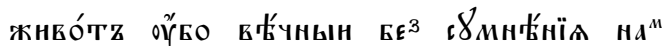
насабдоватн в dubio nos consecuturos credimus (12).

Латинские относительные местоимения в начале предложения передаются указатель- 
Апостольский символ веры (Symbolum Apostolorum) в церковнославянском переводе Дм. Герасимова

ным местоимением, которому может предшествовать, как в примере (5), соединительный союз н:

н в то́мz во́zраст中 - In qua etiam aetate (4),

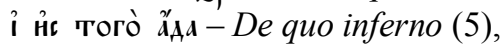

в́ то́н̆ тү̊̆ы - In qua Trinitate (8).

В латинском тексте имеются случаи употребления отложительного самостоятельного (ablativus absolutus), который передается в основном славянским дательным самостоятельным или с помощью предложной конструкции (об этом обороте в Толковой Псалтири Брунона см. [Томеллери, 2013, с. 203-205]):

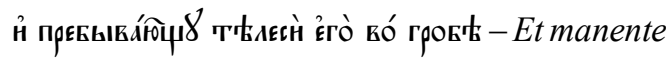
corpore in sepulcro (5),

Rz сконча́нїв ми́ра - Finito mundi termino (7).

В толковании к третьему стиху дательный самостоятельный передает лат. предложную синтагму ессе (вот) + винительный падеж, выражая таким образом синтаксическую зависимость от следующего предложения:

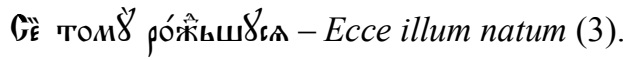

Среди придаточных предложений следует упомянуть инфинитивную конструкцию для передачи латинской конструкции «винительный с инфинитивом» (Accusativus cum infinitivo), причем в церковнославянском переводе подлежащее придаточного предложения выступает обычно в винительном $(8,10,11)$, реже в дательном (9) падежах:

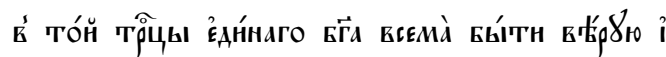
нُспов臬ан - In qua Trinitate unum Deum omnino esse credo et confiteor (8),

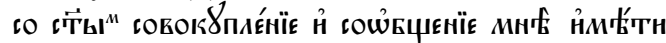
k'p $\gamma_{\text {to }}$ - cum sanctis societatem et communionem me habere credo (9);

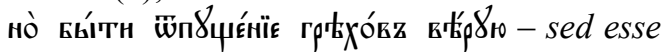
remissionem peccatorum credo (10);

но̀ пло́ть ... восъста́тн вє швъфца́нїє возда́тн - sed carnem ...resurrecturam esse immortalem credo et...rationem reddituram (11).

Что касается лексики, подстрочный принцип перевода, требующий точного количественного соответствия, очень редко нарушается, причем в сторону как увеличения, так и уменьшения количества языковых единиц, используемых при переводе на церковнославянский:

$3^{\mathrm{aH} \varepsilon}-$ eо quod (1),

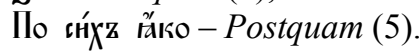

Латинскому термину omnipotens всегда соответствует церковнославянское слово всємог४чїн (passim), в отличие от Символа веры Псевдоафанасия Александрийского, в котором наблюдается лексическое варьироваНИе вєємоГУчї̈н - вєєдержнтєль [ТОМеЛЛСРИ, 2017, S. 119].

Некоторые слова греческого происхождения оставлены непереведенными, когда в глоссе разъясняется происхождение латинского слова:

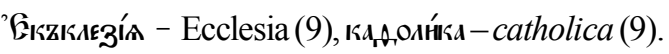

Имя прилагательное catholicus, за исключением только что названного примера, везде в тексте передается как сқворнын (заметка о символах, 9 стих текста и толкование к нему) ${ }^{32}$.

Есть случай, когда одно и то же церковнославянское слово передает разные формы латинского подлинника:

понє́жє-quoniam (1), quia (1).

Кроме этого, в толковании к четвертому стиху дается, согласно с латинским оригиналом, неправильное объяснение имени римского префекта Иудеи Понтия Пилата, которое воспринимается как оттопонимическое прилагательное ${ }^{33}$ :

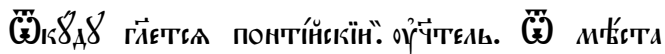

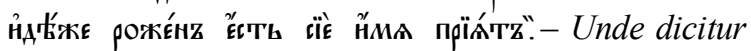
Pontius? M. A loco ubi natus fuit, hoc nomen accepit (4).

Такую же форму мы находим и в старославянском переводе евангельского текста. Р. Матьесен, считая подобную переводческую ошибку слишком грубой и недопустимой для образованных людей, какими были Кирилл и Мефодий, высказывал остроумное предположение, что она могла возникнуть на моравской или паннонской почве, то есть до миссии солунских братьев, вероятно, под влиянием раннего славянского перевода Апостольского символа с латыни [Mathiesen, 1981-1984-1985, p. 258].

Наши фрагментарные наблюдения далеко не исчерпывают всех вопросов, связанных с интерпретацией издаваемого здесь переводного памятника. Мы питаем надежду, что введение в научный оборот текста Апостольского символа веры с толкованиями в переводе Дм. Герасимова привлечет внимание исследователей и тем самым будет способствовать более глубокому изучению всех оставшихся нерешенными вопросов. 


\section{ПРИМЕЧАНИЯ}

${ }^{1}$ Versus memoriales - стихотворное изложение Апостольского символа веры в гекзаметрах для лучшего запоминания, цит. по: [Curtis, 1911, S. 49, прим. 1]; см. также: [Cullmann, 1949, S. 12].

2 Латинский текст с переводом на современный русский язык см. в: [Катехизис..., 2007, с. 29].

${ }^{3}$ Swainson [1875, p. 380-381], Hahn [1897, S. 174-175, прим. 50]; латинский текст [Burn, 1896, p. 12-20; Denzinger, 2009, S. 62-64] исследован в: [Kelly, 1964].

${ }^{4}$ Об этом явно свидетельствует, например, следующая запись: “QUAE A PRESBYTERIS DISCENDA SINT - Haec sunt quae iussa sunt discere omnes ecclesiasticos. Fidem catholicam sancti Athanasii et cetera quaecumque de fide; Symbolum etiam apostolicum; Orationem dominicam ad intelligendum pleniter cum expositione sua [...]" [Boretius, 1883, S. 235; см. также: [Specht, 1885, S. 62-63; Wiegand, 1899, S. 321-322].

5 Это хорошо показывает сравнение обоих текстов [Baier, 1893, S. 121-126].

${ }^{6} \mathrm{O}$ разных видах толкований см. также [Zwierlein, 2002].

7 Текст Апостольского символа веры с толкованиями дается в немецком переводе в работах: [Baier, 1893, S. 132-138; Probst, 1886, S. 91-94].

${ }^{8}$ «Although the creed has no original place in the tradition of the Eastern Orthodox Church, it does appear in some Eastern collections of creeds» [Pelikan, Hotchkiss, 2003, p. 668]. Показательно в этом отношении несколько преувеличенное высказывание Эфесского митрополита Марка, главного доктринального противника унии среди представителей греческой делегации на Ферраро-Флорентийском coбope [Pelikan, 2003, p. 260], о том, что Апостольский символ веры совсем неизвестен грекам: ${ }^{\circ} H \mu \varepsilon \bar{\varsigma} \varsigma$

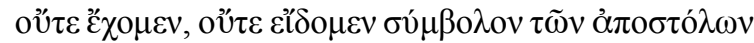
[Blume, 1893, S. 23, прим. 1].

${ }^{9}$ «Das Glaubenssymbolum ist der kürzeste und prägnanteste Ausdruck der christlichen Weltanschauung» [Dörholt, 1898, S. 1].

${ }^{10}$ Постепенное образование текста представлено в виде таблиц в работах: [Blume, 1893, S. 106-107; Schaff, 1878, p. 2-55].

${ }^{11}$ CM.: [Pelikan, Hotchkiss, 2003, p. 667]: «With its uncomplicated formulation of the trinitarian basis of Christian belief, The Apostles' Creed remains the most common baptismal formula in Western Christian churches». Перед погружением в воду крещаемый отвечал на тройной (тринитарный) вопрос о вере [Lietzmann, 1962, S. 167]; описание крещения см.: [Müri, 1931, S. 45; то же: 1976, S. 43] - по Тертуллиану, De baptismo, гл. 6-8, а также Scarapsus св. Пирмина II, 12 [Pirmin, 2010, S. 37-41; то же:
Hauswald, 2006, S. 37-41; Jecker, 1927, S. 43-44]. О функциональных и формальных различиях между литургическими (symbola) и доктринальными (regulae fidei) формулами см.: [Pelikan, 2003, p. 2-4; Westra, 2002, p. 36-38].

12 Загадочная форма происходит, видимо, из причастия excarpsus «извлеченный» [Jecker, 1927, S. 82, прим. 26]; его употребление, указывающее на достоверность передаваемых сведений, отражает языковой узус обиходной канонической литературы [Pirmin, 2010, S. XIX-XX, прим. 48; то же: Hauswald, 2006, S. XIV, прим. 55].

${ }^{13}$ Всего текст Апостольского символа веры приводится там три раза, с незначительными разночтениями [Westra, 2002, p. 136-137].

${ }^{14} \mathrm{CM}$. также сочинениеИсидора Deecclesiasticis officiis, II, XXIII - De symbolo [Isidorus, 1989, p. 9798], английский перевод: [Isidore, 2008, p. 104].

15 Возражения по поводу апостольского характера текста, как отмечено выше, были высказаны за несколько лет до Валлы на ФеррароФлорентийском соборе [Вӓumer, 1893, p. 27]; Vincent [2006, S. 31, прим. 3] выдвигает гипотезу о преемственности позиций Марка и Валлы.

16 Любопытно, что это греческое заимствование в древней латинской традиции выступает в мужском роде, например у Плаута и Катона; форма среднего рода symbolum встречается впервые в «Естественной истории» Плиния Старшего [Müri, 1931, S. 6, прим. 1; то же: Müri, 1976, S. 8, прим. 4]: «Graeci a digitis appellavere, apud nos prisci ungulum vocabant, postea et Graeci et nostri symbolum» [Plinius, Naturalis historia, XXXIII, IV, 10, http://penelope. uchicago.edu/Thayer/L/Roman/Texts/Pliny_the Elder/33*.html, 07.08.2017], английский перевод см.: [Suto, 2012, p. 53]. Авторы классического периода, как правило, избегали его употребления [Schlesinger, 1912, S. 9; Suto, 2012, p. 52].

17 Ученый предлагает значение «договор, заключенный между Богом и человеком при крещении» [Carpenter, 1942, p. 9], тогда как В. Мюри отрицал любую связь Символа веры христианской Церкви со знаком признания (Erkennungs-, Beglaubigungszeichen), относя значение слова к тайным формулам, употреблявшимся в языческих мистериях [Müri, 1931, S. 44, то же 1976, S. 42]; см. также: [Chantraine, 1932, p. 49; Meier-Oeser, 1998, col. 711]. Точку зрения Мюри опровергал Келли, исходя из «западного» характера семантики слова symbolum для обозначения исповедания веры: "A serious objection to this is that the use of symbolum in reference to the creed seems to have originated in the West: the Greek-speaking churches were markedly slow to adopt it» [Rufinus, 1955, p. 102].

${ }^{18}$ Подробнее об этом см., наряду с классическими монографиями: [Caspari, 1866; 1869; 1875; 
Caspari, 1879; Kattenbusch, 1894; 1900; Ghellinck, 1949; Kelly, 1972, p. 368-434], новейшие публикации по этому вопросу: [Kinzig, Markschies, Vinzent, 1999; Riedl, 2004; Vinzent, 2006; Westra, 2002] и приведенную в них литературу.

19 В данном случае лексическое смешение или просто одинаковая передача латинских слов consilium (сzвфтг) и concilium (сzворz), связано не столько с типичной для Новгорода фонетической реализацией буквы с как [s] перед передними гласными [Tomelleri, 2005, p. 26-28], сколько с историческим контекстом вселенских соборов.

${ }^{20}$ В славянском тексте выступает форма множественного числа, тогда как автор «Католикона» прямо, но без комментариев, ссылается на источник своих сведений.

${ }^{21}$ Johannes <Ianuensis>: Jncipit summa que vocatur Catholicon, Nurenberge, 1486.08.21 [BSB-Ink B-15 - GW 3192], http://daten.digitale-sammlungen. $\mathrm{de} / \sim \mathrm{db} / 0003 / \mathrm{bsb} 00036407 /$ images/index.html?id=000 $36407 \&$ groesser $=\&$ fip $=$ eayayztssdasyztswwyztseayaf sdren $\&$ no $=13 \&$ seite $=568(11.08 .2017)$.

22 Допускается возможность объяснения термина collatio как «собрание», «составление» [Wiegand, 1899, S. 71, прим. 2].

${ }^{23}$ См. также: Thomas Aquinas, Scriptum super libros sententiarum, Bologna: Edizioni Studio Domenicano, 2000, http:/www.alim.dfll.univr.it/alim/ letteratura.nsf/(testiID)/3B249BCC55272F75C12571 D0006D8AE5!opendocument (12.07.2017).

${ }^{24}$ В сочинении Вильгельма Дуранда Rationale divinorum officiorum, книга IV, глава XXV (De symbolo), 6-9, Афанасьевский символ веры опережает НикеоКонстантинопольский [Rationale, 1995, p. 362-363; 2013, p. 218-219], но с оговоркой хронологического характера: «hос (то есть Афанасьевский символ веры.B. C. T.) tamen potest dici tertium, nam Nicenum, de quo sequitur, fuit primus in prima Nicena synodo compilatum» [Rationale, 1995, p. 363]-«but it can nevertheless be called the third one, for the Nicene Creed, which follows, came first and was compiled at the First Council of Nicaea» [Rationale, 2013, p. 219].

${ }^{25}$ «symbolum apostolicum ad fidei instructionem, Nic(a)enum ad fidei explicationem, Athanasianum ad fidei defensionem» (цит. по: [Troelstra, 1903, S. 183]; см. также: [Probst, 1886, S. 22, прим. 1], где, однако, читается имя собственное Athanasium вместо формы прилагательного Athanasianum).

${ }^{26}$ Судя по славянскому переводу, начало латинского оригинала могло бы быть Nota quod / $q u i a .$. Отметим попутно, что в одном латинском сборнике 1432 г., хранящемся в Вене, на л. 346 имеется краткая заметка о символах (Adnotatio de symbolis), начало которой гласит: Quattuor sunt symbola [Hübl, 1899, p. 364], см. также: http://manuscripta.at $/ \mathrm{m} 1 /$ hs_detail.php?ID=4620 23.08.2017).

${ }^{27} \mathrm{http}: / /$ reader.digitale-sammlungen.de/de/fs1/ object/display/bsb11202284 00395.html, 12.08.2017).

${ }^{28}$ Список сокращений см. ниже, в издательской части работы. О некоторых трудностях, связанных с датировкой Толковой Псалтири Брунона, см.: [Tomelleri, 2004, p. 71-78]; подробнее о летосчислении в христианской традиции см.: [Кузенков, 2014].

${ }^{29}$ Сведения о нем см.: [Geldner, 1968, S. 162 167; Grimm, 1967, Sp. 1194-1203; Hase, 1885/1967, S. 18-30; Schramm, 1923; Vouilléme, 1922, S. 122124); об изданиях Толковой Псалтири Брунона см.: [Stegmüller, 1950, p. 219-222].

${ }^{30}$ Editio ea singula continet, || quae in prima reperiuntur: textus vero ita dispositus est, ut majori typo medium paginae occupet, glossa vero minori typo ad utrumque latus et in inferiori paginae parte expressa sit» [Bibliotheca Sacra, 1785, p. 402-403]. Подробнее о разных способах распределения текста и толкования см.: [Powitz, 1979; Sautel, 1999].

${ }^{31}$ В круглых скобках указывается стих Апостольского символа веры и соответствующее ему толкование по нашему изданию.

${ }^{32}$ Об истории этого термина в древнеславянской традиции см.: [Подтергера, Томеллери, 2009]; многочисленные примеры из новгородских переводов с латыни собраны в: [Томеллери, 2016].

${ }^{33} \mathrm{O}$ возможном смешении собственного име-

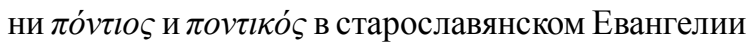
см. также: [Гезен, 1884, с. 36]. 


\section{ГЛАВНАЯ ТЕМА НОМЕРА}

\section{АПОСТОЛЬСКИЙ СИМВОЛ ВЕРЫ В ПЕРЕВОДЕ ДМ. ГЕРАСИМОВА. ИНТЕРЛИНЕАРНОЕ ИЗДАНИЕ ТЕКСТА}

\section{Основной список}

Санкт-Петербург, БАН, нр. 16.12 .7 (Осн. 1287), Толковая Псалтирь Брунона, лл. 334-335об (В).

\section{Разночтения}

Москва, ГИМ, Собрание Барсова, нр. 105, Толковая Псалтирь Брунона, лл. 593об-595об (G);

Москва, ГИМ, Синодальное собрание, нр. 305, Толковая Псалтирь Брунона, лл. 650-652 (Sin);

Москва, ГИМ, Синодальное Собрание, нр. 997, Толковая Псалтирь Брунона (в составе августовского тома Великих Миней Четьих митрополита Макария, Успенский список), лл. 854a-856a (U);

Москва, ГИМ, Собрание Хлудова, нр. 47, Толковая Псалтирь Брунона, лл. 431-433 (X);

Москва, РГБ, ф. 722, нр. 108, Толковая Псалтирь Брунона, лл. 746-748 (М);

Москва, РГБ, Собрание Свято-Троицкой Сергиевой Лавры (Ф. 304.I), нр. 87 (834), Толковая Псалтирь Брунона, лл. 434об-436об (Tr);

Москва, РГБ, Собрание Лукашевича и Маркевича (ф. 152), нр. 110, Из толковой Псалтири, лл. 2об-6 (L);

Санкт-Петербург, РНБ, Собрание Соловецкого монастыря (Ф. 717), нр. 1148 (1039), Толковая Псалтирь Брунона, лл. 766v-770r (Sol);

Санкт-Петербург, РНБ, Собрание Новгородского Софийского собора, нр. 1255, Толковая Псалтирь Брунона, лл. 589об-592 (Sof) ${ }^{1}$.

\section{Список сокращений}

БАН - Библиотека Российской Академии Наук

ГИМ - Государственный Исторический Музей

РГБ - Российская Государственная Библиотека

РНБ - Российская Национальная Библиотека

\footnotetext{
${ }^{1}$ В одном сборнике XVII-XVIII вв. (РНБ, Собрание Новгородского Софийского собора № 1461) помещен, вместе с другими отрывками из Толковой Псалтири Брунона (лл. 236об-247об), и существенно сокращенный вариант Апостольского символа веры (лл. 2430б-244). Свидетельство этой поздней рукописи не принимается здесь во внимание.
} 
Апостольский символ веры (Symbolum Apostolorum) в церковнославянском переводе Дм. Герасимова

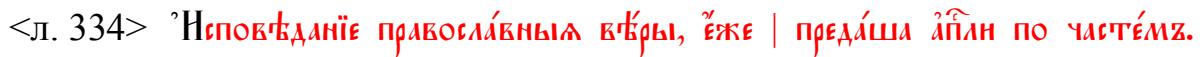

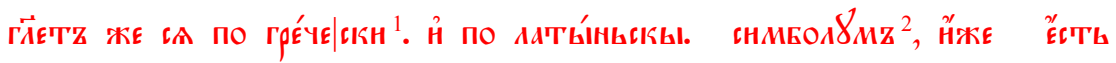

symbolum est

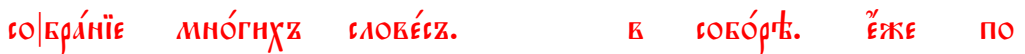

collectio sermonum. ut in consilio. quod secundum

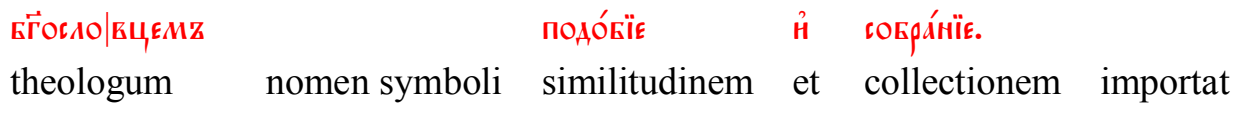

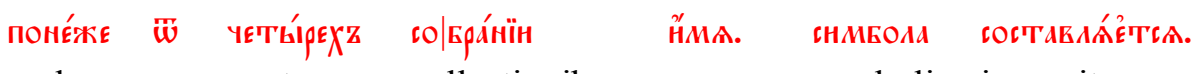

unde a quatuor collectionibus nomen symboli imponitur.

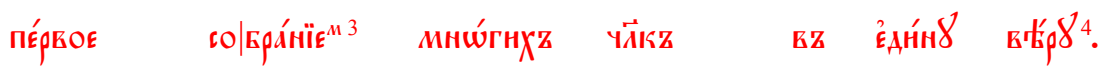

Primo a collectione multorum hominum in unam fidem.

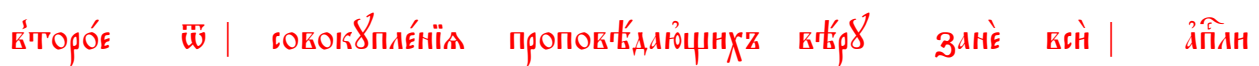

Secundo a collectione praedicantium fidem: quia omnes apostoli

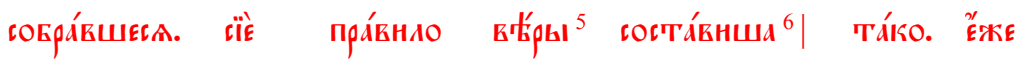

collecti hanc regulam fidei ediderunt,

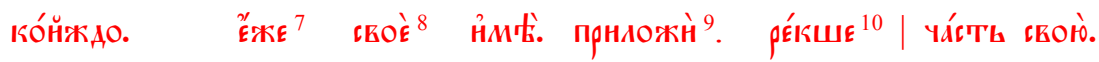

unusquisque quod suum est apponens.

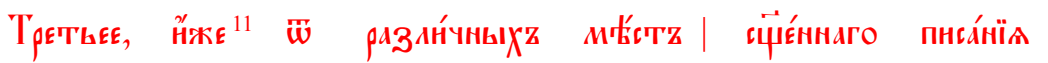

Tertio, quia ex diversis locis Sacrae Scripturae

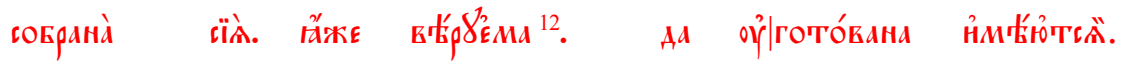

colliguntur ea quae credenda sunt, ut in promptu habeantur.

${ }^{1} \mathbf{L}$ err. Гคєчєєкї̈.

${ }^{2} \operatorname{Tr}$ err. Аон $^{\mathrm{M}} \mathrm{EOAx}^{\mathrm{M}} ; \mathbf{G}, \mathbf{M}$ от.

${ }_{3}^{3}$ B, Tr err. собра́нїє, еm. U, Sol, Sof, G, M, X, Sin, L.

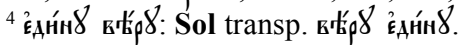

${ }^{5} \mathbf{X}$ om.

${ }^{6} \mathbf{T r}$ err. юосогта́́ншша.

${ }^{7} \mathbf{G}, \mathbf{M}$ น้สต.

${ }^{8} \mathbf{M}$ err. своское́.

${ }^{9}$ Sol corr. полр ${ }^{\mu_{\text {}}}$ жн, prius положн.

${ }^{10}$ B err. ṕєєша, em. U, Sol, Sof, Tr, G, M, X, Sin, L.

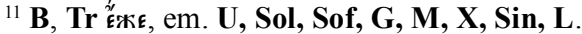

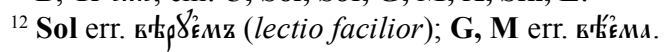




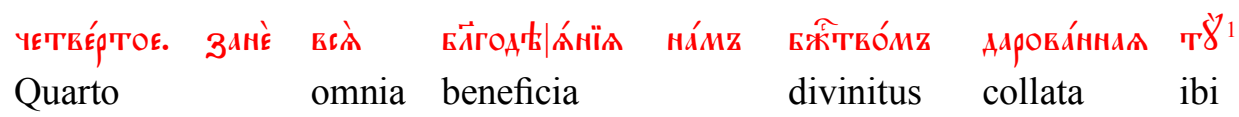

соврана̀. |

colliguntur.

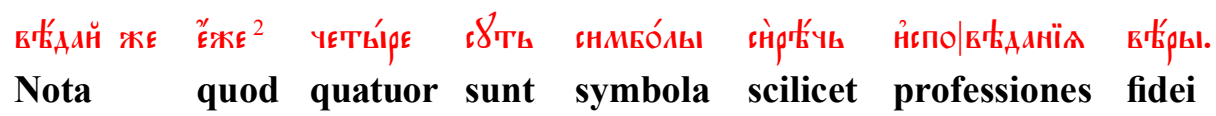

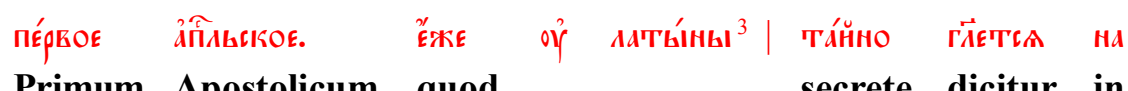

Primum Apostolicum quod secrete dicitur in

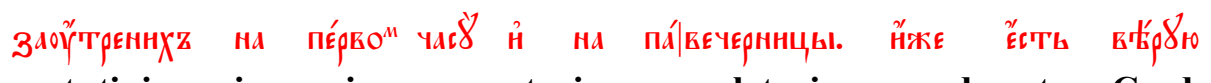

matutinis in prima et in completorio, quod est: Credo

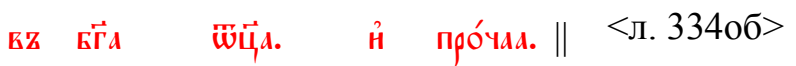

in Deum Patrem et caetera.

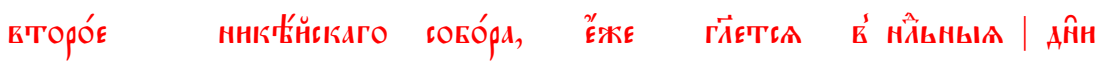

Secundum Nicaeni concilii, quod dicitur (in) diebus dominicis

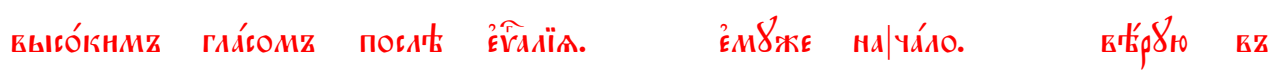

alta voce post Evangelium, cuius initium est: Credo in

Ëни́ного Б̈ं̈.

unum Deum.

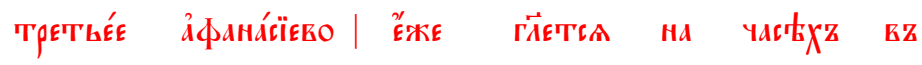

Tertium Athanasii, quod dicitur in horis in

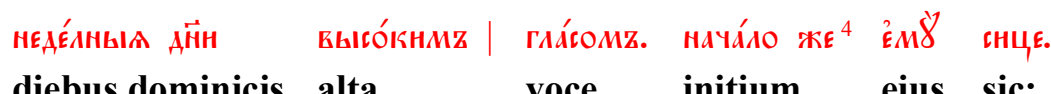

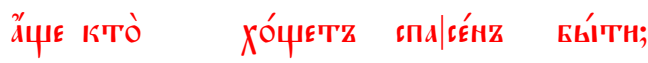

Quicumque vult salvus esse.

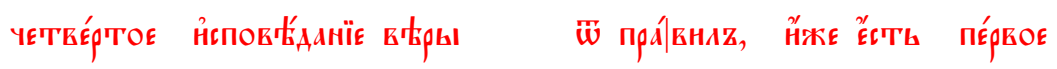

Quartum symbolum est iuris, scilicet primus

${ }^{1}$ Sol Toy ${ }^{\mathrm{T}}$.

${ }^{2}$ U нже.

${ }^{3}$ Sol латынz fortasse recte.

${ }^{4} \mathbf{X}$ om. 
Апостольский символ веры (Symbolum Apostolorum) в церковнославянском переводе Дм. Герасимова

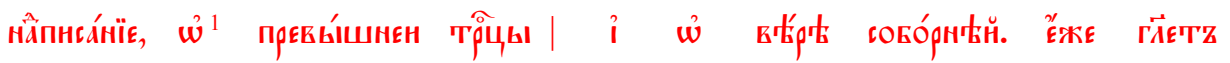

titulus de summa Trinitate et de fide catholica, ut ait

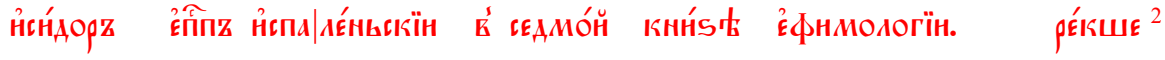

Isidorus episcopus septimo libro Etymologiarum,

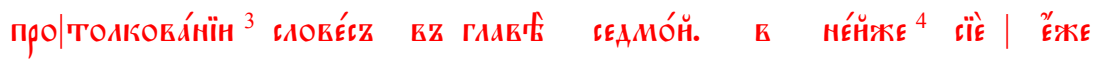

capite septimo, in quo id quod

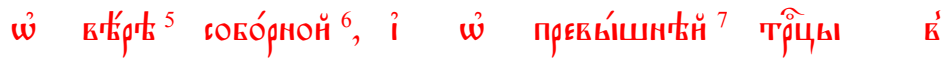

de fide catholica et de summa Trinitate in

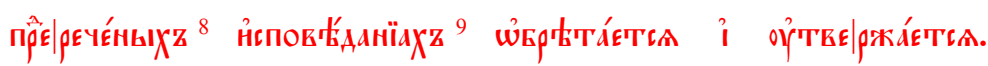

praedictis symbolis continetur, confirmatur et repetitur.

(1) пе́трв ${ }^{10 "}$.

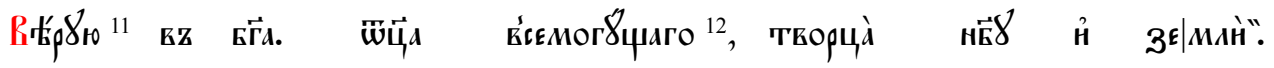

Credo in Deum Patrem omnipotentem, creatorem coeli et terrae.

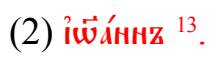

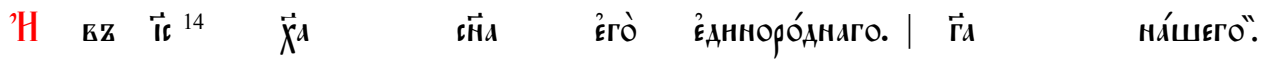

Et in Iesum Christum Filium eius unicum Dominum nostrum

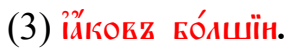

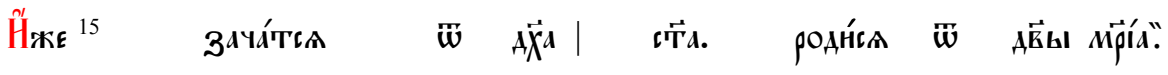

Qui conceptus est de Spiritu sancto, natus ex Maria virgine.

${ }^{1} \mathbf{G}, \mathbf{M}$ err. $\mathbb{w}$.

2 ёфнмологїн. ре́кшє: G, М ёфнмоло́гн ї ре́єшіє.

${ }^{3} \mathbf{U}$ err. протованїн, Sof протованї (add. litteras suprascriptas лко).

${ }^{4} \mathbf{G}, \mathbf{M}$ Hé

${ }^{5} \mathbf{U}$ err. въьры.

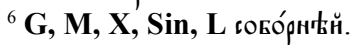

${ }^{7}$ M err. прєвьі́шнє.

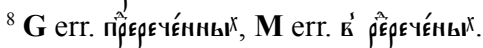

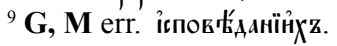

${ }^{10} \mathbf{G}, \mathbf{M}, \mathbf{X}$, Sin om.

${ }^{11}$ Sol add. in marg. litteras alphabeti cyrillici а в в г А є S 3 н ad omnem versum symboli, Sof add. hic in marg. litteram a.

${ }^{12} \mathbf{G}, \mathbf{M}, \mathbf{X}$, Sin add. пе́ T $\rho \mathbf{z}$.

${ }^{13} \mathbf{U}$, Sol, Sof, Tr, X, Sin, L hizánz.

${ }^{14} \mathbf{G}, \mathbf{M} \overrightarrow{\mathrm{ca}}$.

${ }^{15} \mathbf{G}, \mathbf{M}$ คै. 
(4) ӓндрюь̆н.

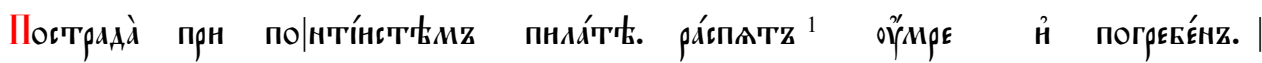

Passus sub Pontio Pilato, crucifixus, mortuus et sepultus.

(5) фомѝ.

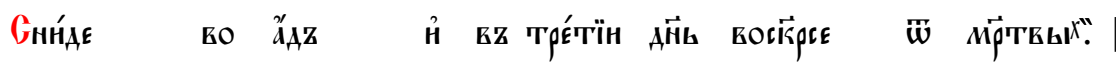

Descendit ad inferna, tertia die resurrexit a mortuis.

(6) варфолом 'кён̆.

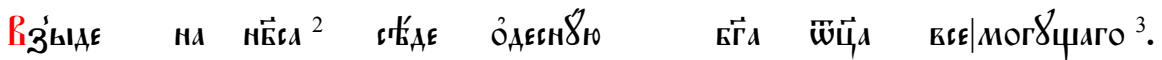

Ascendit ad coelos, sedet addexteram Dei Patris omnipotentis.

(7) фняніппв.

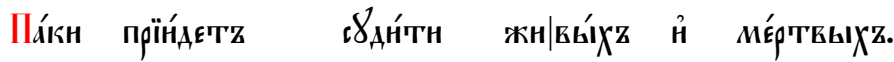

Inde venturus est iudicare vivos et mortuos.

(8) матф\%ён.

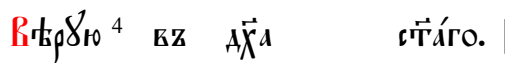

Credo in Spiritum sanctum,

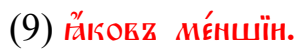

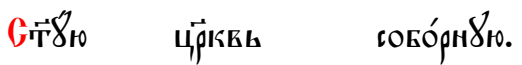

sanctam Ecclesiam catholicam,

(10) снмонг ${ }^{5}$ ка|наннтт ${ }^{6}$.

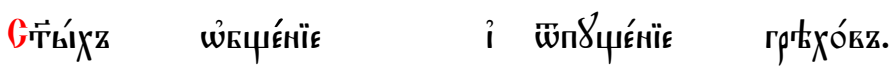

sanctorum communionem, remissionem peccatorum,

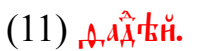

${ }^{1} \mathbf{U}$ add. $\mathbf{H}$.

${ }^{2} \mathbf{B}$ add. $\mathbf{H}$.

${ }^{3} \mathbf{L}$ всеногУЧего.

${ }^{4} \mathbf{M}, \mathbf{G}$ err. k'tep.

${ }^{5}$ Sof err. снмоно.

${ }^{6}$ B, U, Sof каннтz; Sol, Tr ка́ноннт"; G, M, X, Sin, L кананнтт. 


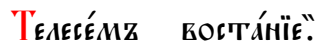

carnis resurrectionem,

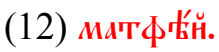

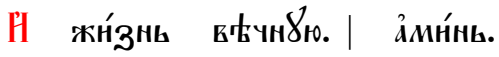

et vitam aeternam.

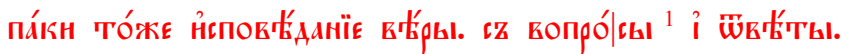

$<559>$ (1) Credo in Deum Patrem omnipotentem, creatorem coeli et terrae.

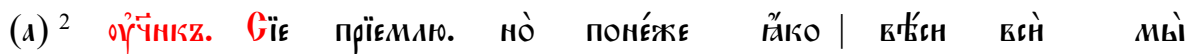

(a) D. Ista suscipio, sed quoniam, sicut nosti, omnes nos

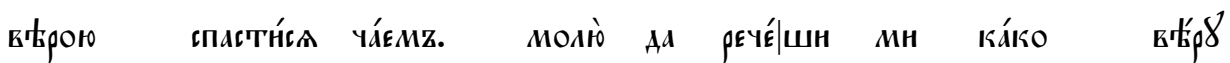

per fidem salvari credimus, rogo ut dicas mihi quomodo fidem

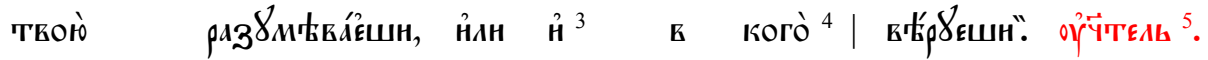

tuam intelligas, vel etiam in quem credas. $M$.

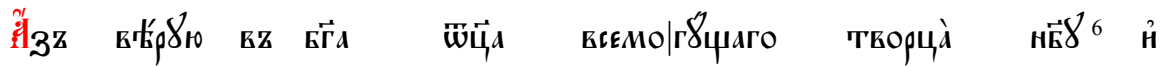

Ego credo in Deum, Patrem omnipotentem, creatorem coeli et

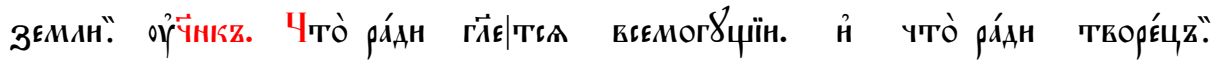

terrae. D. Quare dicitur omnipotens, et quare creator?

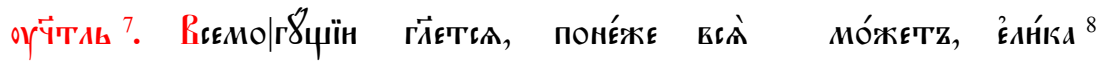

M. Omnipotens dicitur, quia omnia potest quaecumque

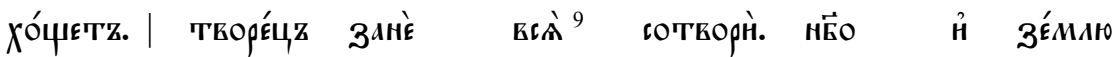

vult; creator, eo quod omnia creavit, coelum et terram,

H̉ $^{10}$ Mópe. Ḣ Ec⿱亠̀. ।

[et] mare et omnia.

${ }^{1}$ Sic B, Tr, X; fortasse recte U, Sol, Sof, G, M, Sin, L вогпро́ыы.

${ }^{2}$ Sic Sol; om. B, U, Sof, Tr, G, M, X, Sin, L.

${ }^{3}$ B, U, Sof, Tr, G, M, X, Sin, L om.; recte Sol.

${ }^{4}$ Sol кое́то.

${ }^{5}$ Sol add. in marg. litteram a.

${ }^{6}$ Sol HËंн.

${ }^{7} \mathbf{G}, \mathbf{M}$ err. огे

${ }^{8} \operatorname{Tr}$ ésú́ro.

${ }^{9} \mathbf{G}$ add. мо́жє

${ }^{10}$ Sol, $\mathbf{X}$ om. 
(2) Et in Iesum Christum Filium eius unicum Dominum nostrum.

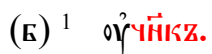

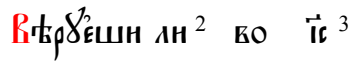
$\vec{x}^{a}$.

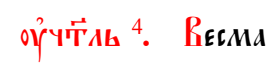
(b) D.
Credis
in Iesum
Christum? M.
Omnino

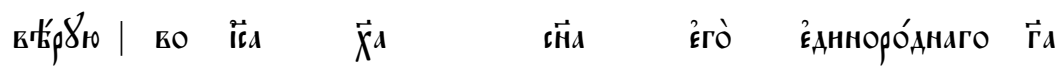

credo in Iesum Christum Filium eius unicum Dominum

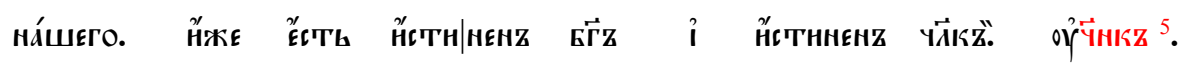

nostrum, qui est verus Deus et verus homo. D.

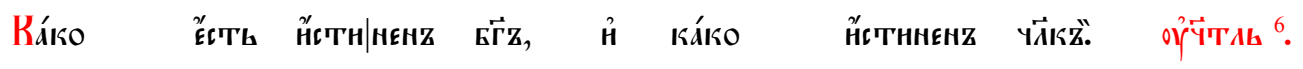

Quomodo Deus, et quomodo verus homo? M.

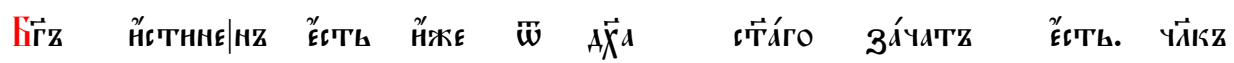

Deus verus est, quia de Spiritu sancto conceptus est, homo

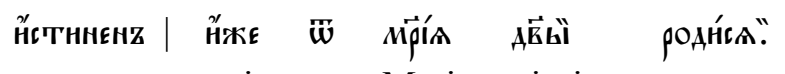

verus, quia ex Maria virgine natus est.

(3) Qui conceptus est de Spiritu sancto, natus ex Maria virgine.

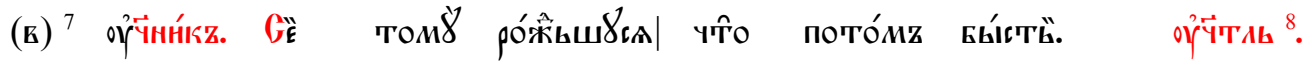
(c) D. Ecce illum natum. Quid postea factum est? M.

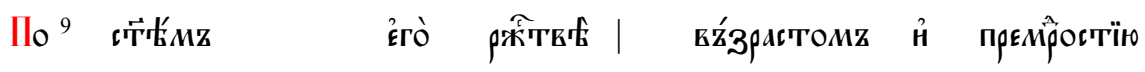
Post sanctam enim eius nativitatem aetate et sapientia

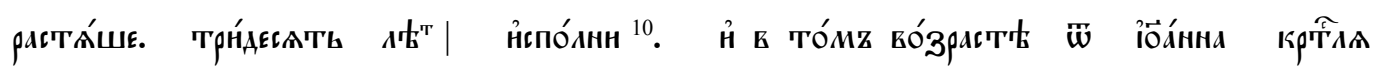

crescens, triginta annos implevit ${ }^{11}$. In qua etiam aetate a Ioanne Baptista

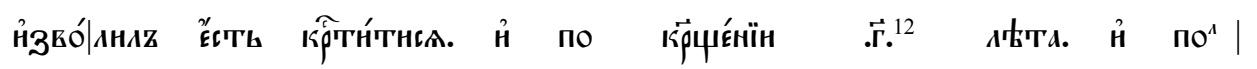

dignatus est baptizari, et post baptismum tribus annis et dimidio

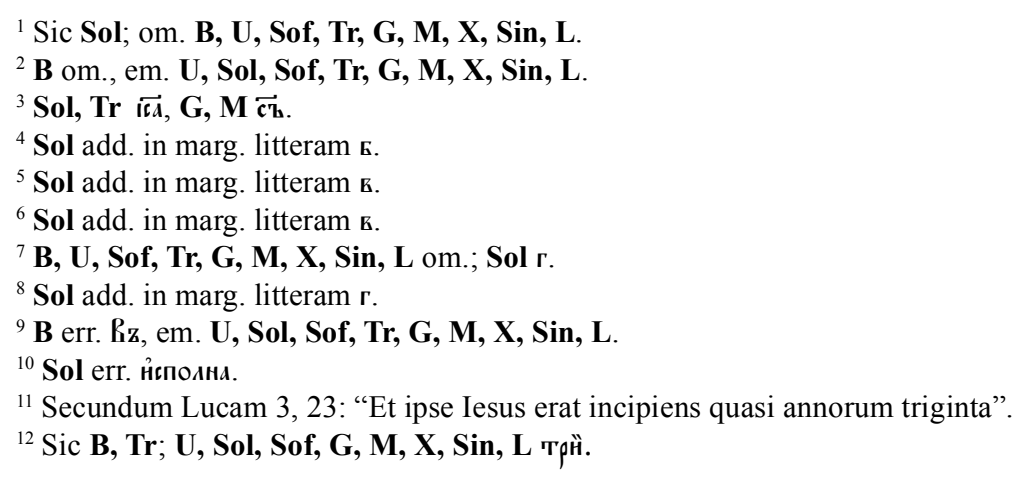


Апостольский символ веры (Symbolum Apostolorum) в церковнославянском переводе Дм. Герасимова

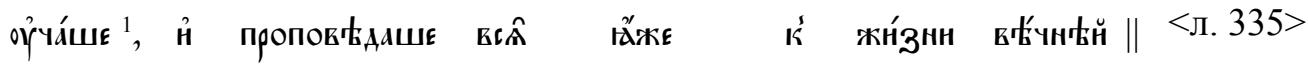

docuit et praedicavit omnia quae ad vitam aeternam

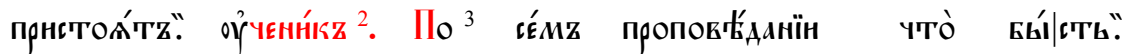

pertinent. D. Post hanc praedicationem quid factum est?

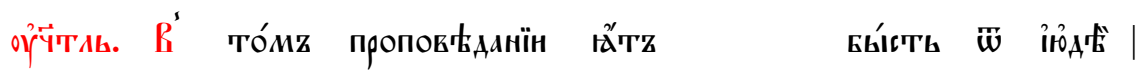

M. In ipsa praedicatione comprehensus est a Iudaeis

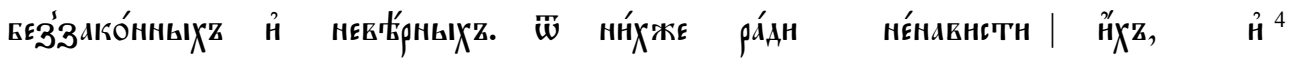
iniquis et perfidis, a quibus propter invidiam illorum et

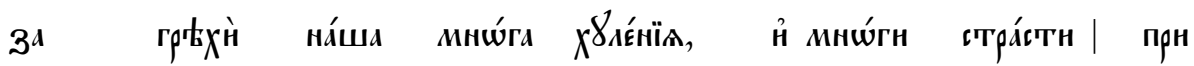

propter peccata nostra multa blasphema multasque passiones sub

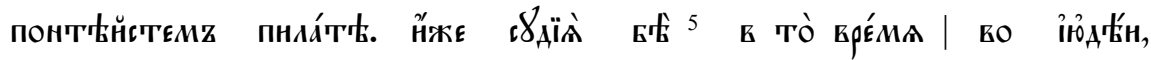

Pontio Pilato, qui iudex erat illo tempore in Iudaea,

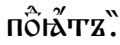

sustinuit.

(4) Passus sub Pontio Pilato, crucifixus, mortuus et sepultus.

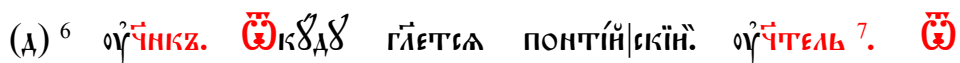

(d) D. Unde dicitur Pontius? M. A

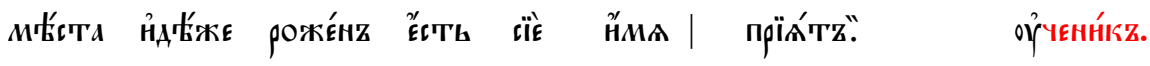

$\operatorname{loco}^{8}$ ubi natus fuit, hoc nomen ac $\|<560>$ cepit. D.

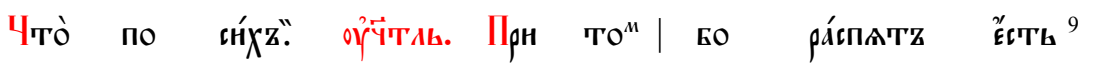

Quid post haec? M. Sub illo enim crucifixus est,

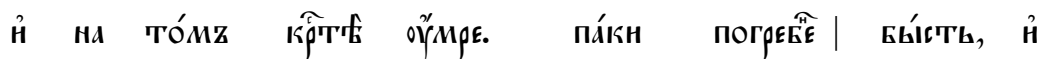

et in eadem cruce mortuus, deinde sepultus est. Et

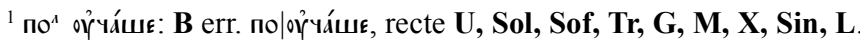

${ }^{2}$ Sol ant. г.

${ }^{3} \mathbf{U}$ 'H nо.

${ }^{4} \mathbf{G}$ om.

${ }^{5} \mathrm{~B}$ corr. F't, prius r't.

${ }^{6}$ Sic Sol; om. B, U, Sof, Tr, G, M, X, Sin, L.

${ }^{7}$ Sol add. in marg. litteram ${ }_{\text {A. }}$.

${ }^{8}$ В издании Кобергера: $D$ unde dicitur pontius $d$ M a loco...

${ }^{9} \mathbf{U}$ вй́сть. 


\section{ГЛАВНАЯ ТЕМА НОМЕРА}

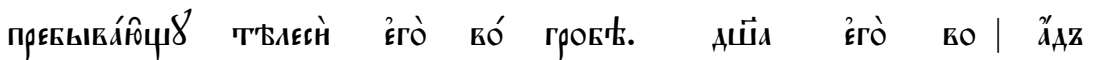

manente corpore in sepulcro, anima eius ad inferna

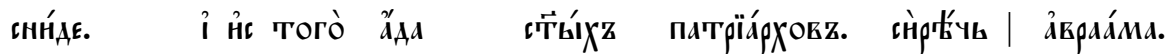

descendit. De quo inferno sanctos patriarchas, scilicet Abraham,

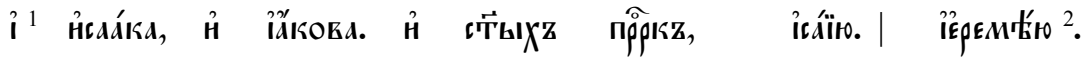

Isaac et Iacob et sanctos prophetas Isaiam, Ieremiam,

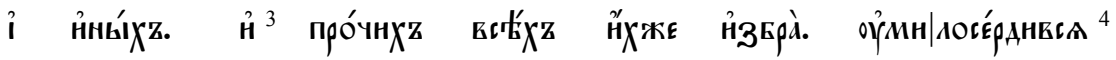

et reliquos, et caeteros omnes quos elegit, misericorditer

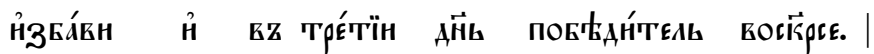

liberavit. Et tertia die victor resurrexit.

(5) Descendit ad inferna, tertia die resurrexit a mortuis.

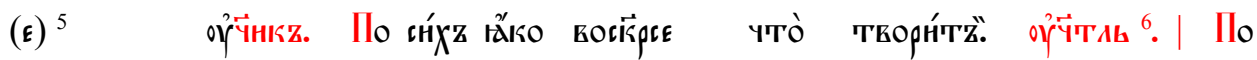

(e) D. Postquam resurrexit quid fecit? M. Post

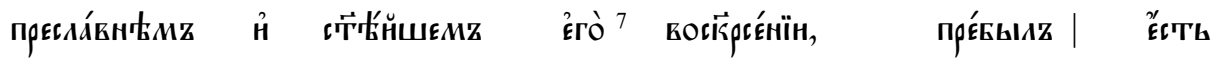

nobilissimam et sanctissimam eius resurrectionem, conversatus est

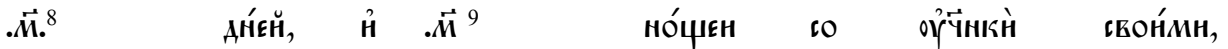

quadraginta diebus et quadraginta noctibus cum discipulis suis:

i मảdè

et manducavit cum illis, multa docens et loquens de regno Dei ${ }^{10}$.

(6) Ascendit ad coelos, sedet ad dexteram Dei Patris omnipotentis.

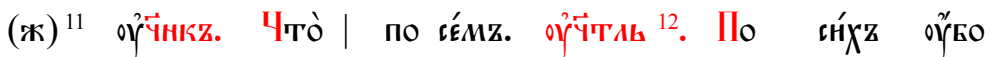

(f) D. Quid postea? M. Post haec vero

${ }^{1} \mathbf{G}$ om.

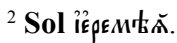

${ }^{3} \mathrm{Tr}$ om.

${ }^{4} \mathbf{X}$ add. $\dot{H}$.

${ }^{5}$ Sic Sol; om. B, U, Sof, Tr, G, M, X, Sin, L.

${ }^{6}$ Sol add. in marg. litteram $\boldsymbol{E}$.

${ }^{7}$ Tr om.

${ }^{8}$ Sol YeTtLIPEAECATZ.

${ }^{9}$ Sol YeTHA

${ }^{10}$ Actus apostolorum 1, 3: "per dies quadraginta apparens eis et loquens de regno Dei".

${ }^{11}$ Sic Sol; om. B, U, Sof, Tr, G, M, X, Sin, L.

${ }^{12}$ Sol add. in marg. litteram $\boldsymbol{*}$. 


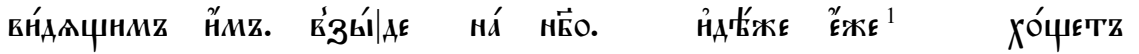
videntibus illis, ascendit in coelum, ubi quomodo vult

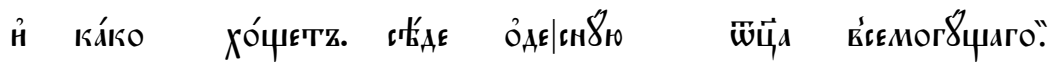

et qualiter vult, sedet ad dexteram Patris omnipotentis.

(7) Inde venturus est iudicare vivos et mortuos.

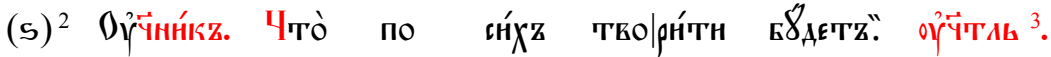

(g) D. Quid post haec facturus erit? M.

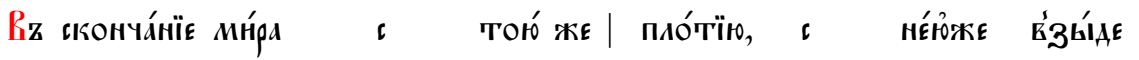

Finito mundi termino, cum ipso corpore, cum quo ascendit

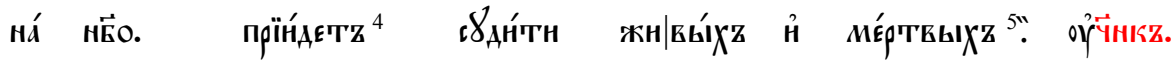

in coelum, venturus est iudicare vivos et mortuos. D.

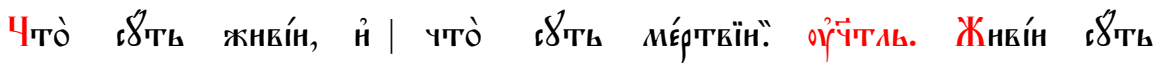

Quid sunt vivi et quid sunt mortui? M. Vivi

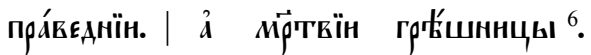

iusti, mortui peccatores.

(8) Credo in Spiritum sanctum

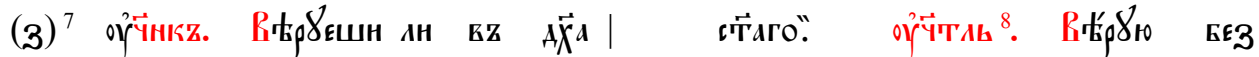

(h) D. Credis in Spiritum sanctum? M. Credo sine

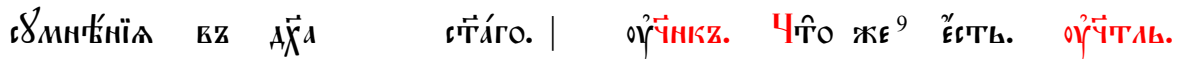

dubio in Spiritum sanctum. D. Quid est? M.

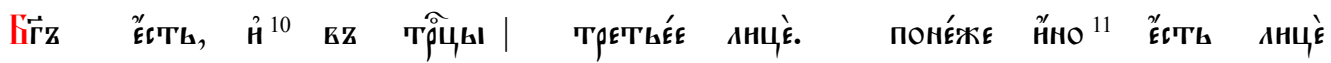

Deus est et in Trinitate tertia persona, quia alia est persona

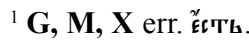

${ }^{2}$ Sic Sol; om. B, U, Sof, Tr, G, M, X, Sin, L.

${ }^{3}$ Sol add. in marg. litteram $\mathrm{S}$.

${ }^{4} \mathbf{G}$ err. Прї̈нёТетт.

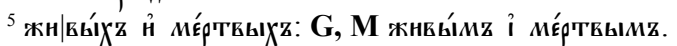

${ }^{6} \mathbf{G}$ грѓ́ш|нїн.

${ }^{7}$ Sic Sol; om. B, U, Sof, Tr, G, M, X, Sin, L.

${ }^{8}$ Sol add. in marg. litteram 3 .

${ }^{9}$ B om., em. U, Sol, Sof, Tr, G, M, X, Sin, L.

${ }^{10} \mathbf{U}$ н̆жк.

${ }^{11} \mathbf{U}$, Sof, Tr, Sin, L ніноє'. 


\section{ГЛАВНАЯ ТЕМА НОМЕРА}

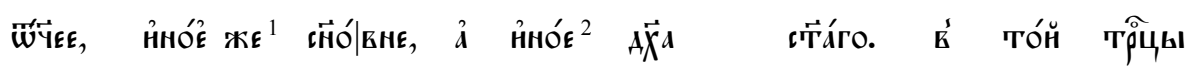

Patris, alia Filii, alia Spiritus sancti. In qua Trinitate

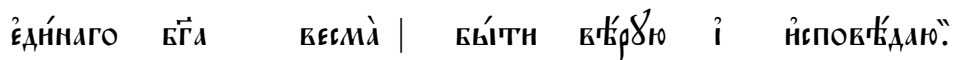

unum Deum omnino esse credo et confiteor.

(9) Sanctam Ecclesiam catholicam, Sanctorum communionem.

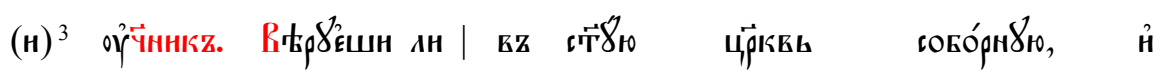

(i) D. Credis in sanctam Ecclesiam catholicam, et ${ }^{4}$

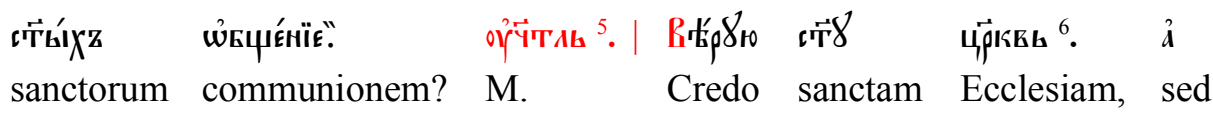

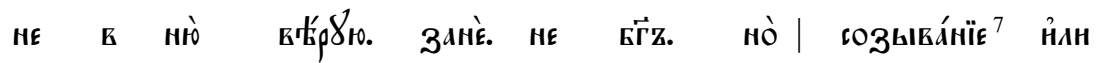

non in illam credo, quia non Deus, sed convocatio vel

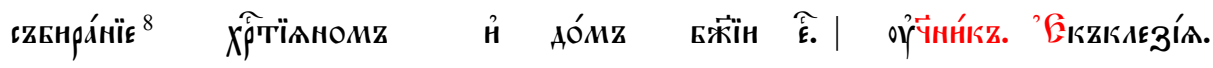

congregatio Christianorum et domus Dei est. D. Ecclesia

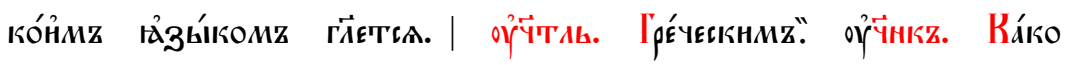

qua lingua dicitur? M. Graeca. D. Quid

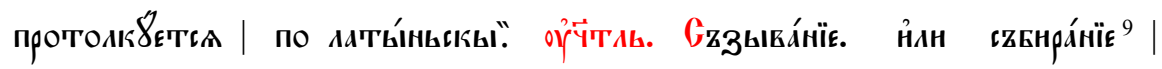

interpretatur latine? M. Convocatio seu congregatio

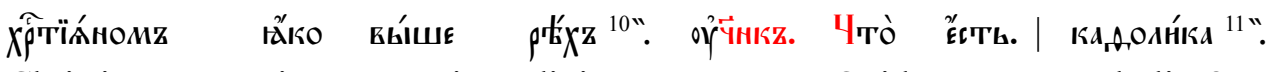

Christianorum, sicut superius dixi. D. Quid est catholica?

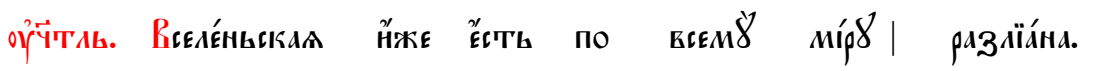

M. Universalis, id est per totum orbem diffusa.

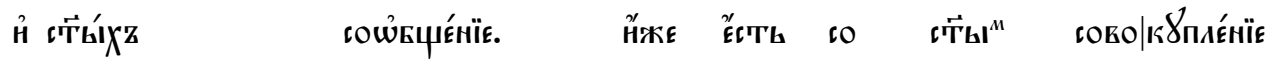

Sanctorum quoque communionem, id est cum sanctis societatem

$\mathbf{G}, \mathbf{M}$ err. йно ё́ть.

${ }^{2} \mathrm{Sic} \mathbf{B}$; fortasse recte $\mathbf{U}, \mathbf{S o l}, \mathbf{S o f}, \mathbf{T r}, \mathbf{G}, \mathbf{M}, \mathbf{X}, \operatorname{Sin}, \mathbf{L}$ н̈но.

${ }^{3}$ Sic Sol; om. B, U, Sof, Tr, G, M, X, Sin, L.

${ }^{4}$ В издании Кобергера: Credis in sanctam ecclesiam catholicam $i$ et sanctorum communionem.

${ }^{5}$ Sol add. in marg. litteram $\mathbf{~}$.

${ }^{6}$ сово́рн

${ }^{7}$ B, U созва́нїє, еm. Sol, Sof, Tr, G, M, X, Sin, L созықа́нїє.

${ }^{8}$ G, М говра́нї.

${ }^{9}$ U сzвра́нїв.

${ }^{10}$ Sol err. príx

${ }^{11}$ В кариданіка, recte U, Sol, Sof, Tr, G, M, X, Sin, L. 
Апостольский символ веры (Symbolum Apostolorum) в церковнославянском переводе Дм. Герасимова

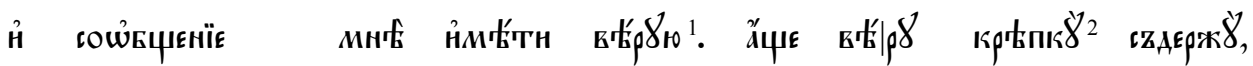

et communionem me habere credo, si fidem firmiter tenuero

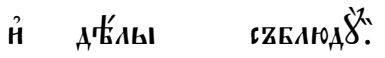

et operibus servavero.

(10) Remissionem peccatorum.

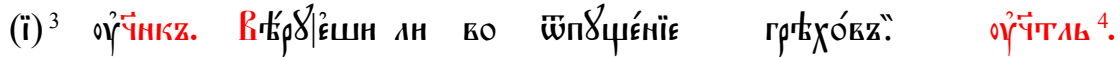

(k) D. Credis in remissionem peccatorum? M.

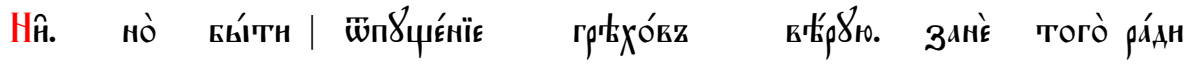

Non, sed esse remissionem peccatorum credo, quia propter hoc

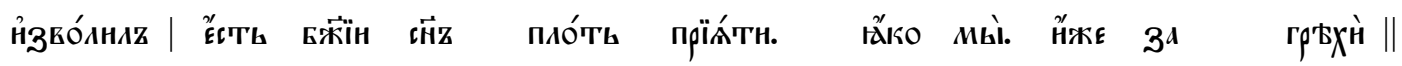

dignatus est Dei Filius carnem assumere, ut nos, qui propter peccata

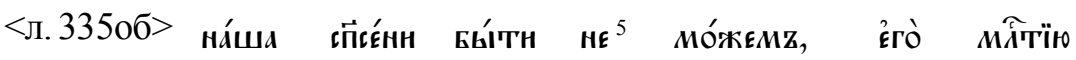

nostra salvi esse non poteramus, eius misericordia

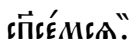

salvaremur.

(11) Carnis resurrectionem.

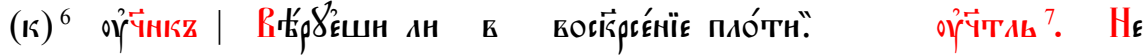

(l) D. Credis in carnis resurrectionem? M. Non

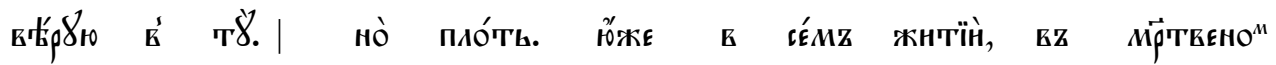

credo in illam $^{8}$, sed carnem, quam in hac vita sub mortali

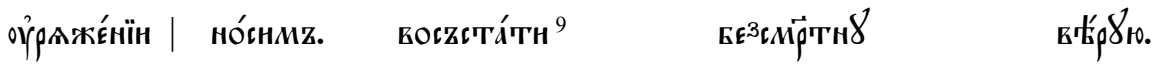

conditione portamus, resurrecturam esse immorta $\mid<561>$ lem credo,

${ }^{1} \mathbf{G}, \mathbf{M}, \mathbf{X}$ err. в̌́poro.

${ }^{2}$ Sol кр'ьпко.

${ }^{3}$ Sic Sol; om. B, U, Sof, Tr, G, M, X, Sin, L.

${ }^{4}$ Sol add. in marg. litteram ï.

${ }^{5} \mathbf{U}$ om.

${ }^{6} \mathrm{Sic}$ Sol; om. B, U, Sof, Tr, G, M, X, Sin, L.

${ }^{7}$ Sol add. in marg. litteram $\kappa$.

${ }^{8}$ Отрицательный ответ ошибочно воспринимается Г. Эвансом в значении «не только»: “Do you believe in the resurrection of the flesh?' asks the pupil. "I do not believe in that [alone], but I believe that the flesh which we have in this life in our mortal condition, is to be resurrected immortally, and that the rational soul will rejoin it as its companion" [Evans, 1979, p. 467].

${ }_{9}^{9}$ B, U, Sof, Tr въгта́тн; G, M, X, Sin, L вогта́тн; fortasse recte Sol вогzстатн. 

н $3^{\text {a }}$ прнчастї
Ѐं | Аш̈н
ఊъъциа́нїв возАа́тн".
et pro consortio
eius animam
rationem reddituram.

(12) Et vitam aeternam.

\begin{tabular}{|c|c|c|c|}
\hline & Vitam & aeternam vero & $\begin{array}{l}\mathbf{E \varepsilon ^ { 3 }} \\
\text { sine }\end{array}$ \\
\hline
\end{tabular}

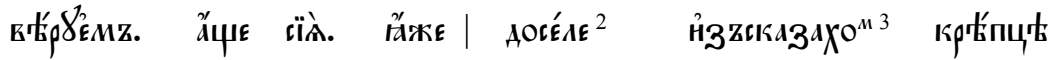

credimus: si ista, quae hucusque exposuimus, firmiter

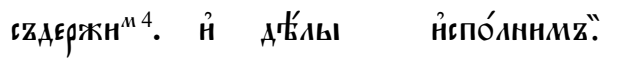

teneamus et operibus impleamus.

1 Здесь не должно быть этого слова. Переводчик, по-видимому, перепутал строчную латинскую букву $m$, относящуюся к основному тексту Символа, с прописной буквой $M$, указывающей на Magister.

${ }^{2}$ B, Sof, Tr, G, M, X, Sin, L add. ï; recte Sol, U.

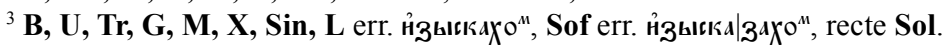

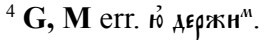




\section{СПИСОК ЛИТЕРАТУРЫ}

Гезен А. М., 1884. Очерки и заметки из области филологии, истории и философии. Вып. 1 : История славянского перевода Символов Веры. Критико-палеографические заметки с приложением четырех снимков. СПб. : Типография Императорской Академии Наук. 128 c.

Катехизис..., 2007. Катехизис католической церкви. Компендиум. М. : Культурный центр «Духовная библиотека». $216 \mathrm{c}$.

Кузенков П. В., 2014. Христианские хронологические системы. История летосчисления в святоотеческой и восточнохристианской традиции. М. : Русский издательский центр. 992 с.

Подтергера И. А., Томеллери В. С., 2009. Catholicus: гұворьнын - каддолнчєекї̈н - Православьнын (из истории термина). Часть $1 / /$ Русский язык в научном освещении. № 1 (17). С. 44-108. Электрон. текстовые дан. Режим доступа: http://www.ruslang.ru/doc/rjano17. pdf (24.08.2017).

Проповеди, 1901. Проповеди Гавриила Бужинского (1717-1727). Ист.-лит. материал из эпохи преобразования. Изд. по рукоп. Моск. духов. акад. Евгений Петухов. Юрьев : Типография Маттисен. XII, $676 \mathrm{c}$.

Томеллери В. С., 2013. О некоторых синтаксических особенностях Толковой Псалтири Брунона (1535). Дательный самостоятельный, инфинитивные и причастные конструкции, герундий и герундив // Лингвистическое источниковедение и история русского языка 2012-2013 : Сб. статей. М. : Древлехранилище. С. 196-225. Электрон. текстовые дан. Режим доступа: http://www.ruslang.ru/ doc/lingistoch/2012-2013/10-tomelleri.pdf (08.08.2017).

Томеллери В. С., 2016. Некоторые заметки о терминологии переводных сочинений: славянская передача термина «catholicus» в новгородских переводах с латыни // Rossica Olomucensia. Vol. LV, num. 2. S. 5-42. Электрон. текстовые дан. Режим доступа: http://www.rusistika. upol.cz/fileadmin/ksl/rusistika/rossica/Rossica Olomucensia_2016_2.pdf (24.08.2017).

Томеллери В. С., 2017. «Исповедание веры» Псевдоафанасия Александрийского (Symbolum Athanasii) в церковнославянском переводе Дмитрия Герасимова (Введение. Интерлинеарное издание) // Latinitas in the Slavonic World. Nine case studies / ed. by V. S. Tomelleri, I. V. Verner with the collaboration of A. Lukianowicz. Frankfurt am Main et al. : Lang. S. 113-171 [Specimina Philologiae Slavicae, Band 192].
Успенский Б. А., 2002. История русского литературного языка (XI-XVII вв.), 3-е изд., испр. и доп. М. : Аспект Пресс. 558 с.

Ashwin-Siejkowski P., 2009. The Apostles' Creed and its early christian context. London; New York : T\&T Clark International. $197 \mathrm{p}$.

Baier J., 1893. Der heilige Bruno, Bischof von Würzburg, als Katechet: Ein Beitrag zur deutschen Schulgeschichte. Würzburg : Godel. $168 \mathrm{~S}$.

Bäumer S., 1893. Das apostolische Glaubensbekenntnis. Seine Geschichte und sein Inhalt. Mainz : Kirchheim. VIII, 240 S.

Bibliotheca sacra, 1785. Bibliotheca sacra post cl. cl. v.v. Jacobi Le Long et C.F. Boerneri iteratas curas ordine disposita, emendata suppleta, continuata ab Andrea Gottlieb Masch sereniss. duci regn. megapol. a sacris et consil. eccles., et ecclesiar. circuli Stargard. et ducatus Raceburg. superattendente, partis secundae de versionibus librorum sacrorum volumen tertium de versionibus latinis, Halae : J. Jac. Gebaueri. VI, 353-754 S. Электрон. текстовые дан. Режим доступа: http://digitale.bibliothek.uni-halle.de/vd18/ content/titleinfo/3142350 (24.08.2017).

Blume C., 1893. Das apostolische Glaubensbekenntnis. Eine apologetisch-geschichtliche Studie, mit Rücksicht auf den „Kampf um das Apostolicum". Freiburg im Breisgau : Herder'sche Verlagshandlung. XVI, 304 S.

Boretius A., 1883. Capitularia regum Francorum, denuo edidit Alfredus Boretius, tomus primus. Hannoverae : Impensis bibliopolii Hahniani. $462 \mathrm{~S}$. Электрон. текстовые дан. Режим доступа: http:// daten.digitale-sammlungen.de/ db/bsb00000820/ images/ (01.07.2017).

Brady M. T., 1957. The Apostles and the Creed in manuscripts of The Pore Caitif // Speculum. Vol. 32, no. 2. P. 323-325.

Bühler C. F., 1953. The Apostles and the Creed // Speculum. Vol. 28, no. 2. P. 335-339 (переиздание: Bühler C.F. Early Books and Manuscripts. Forty Years of Research. New York : The Grolier Club ; The Pierpont Morgan Library, 1973. P. 484-489).

Burn A. E., 1896. The Athanasian Creed and its early commentaries. Cambridge : University Press. XCIX, 68 p. [Texts and studies, Contributions to biblical and patristic literature, vol. IV, no. 1].

Burn A. E., 1899. Neue Texte zur Geschichte des apostolischen Symbols // Zeitschrift für Kirchengeschichte. Band 18, Heft 2. S. 179-190.

Carpenter H. J., 1942. "Symbolum" as a title of the Creed // The Journal of Theological Studies. Vol. os-XLIII, iss. 169-170. P. 1-11. DOI: https://doi.org/10.1093/jts/os-XLIII.169-170.1 
Caspari C. P., 1866. Ungedruckte, unbeachtete und wenig beachtete Quellen zur Geschichte des Taufsymbols und der Glaubensregel. Band I. Christiania : Malling. VIII, 305 S. (репринт: Bruxelles : Culture et Civilisation, 1964).

Caspari C. P., 1869. Ungedruckte, unbeachtete und wenig beachtete Quellen zur Geschichte des Taufsymbols und der Glaubensregel. Band II. Christiania : Malling. 305 S. (репринт: Bruxelles : Culture et Civilisation, 1964).

Caspari C. P., 1875. Ungedruckte, unbeachtete und wenig beachtete Quellen zur Geschichte des Taufsymbols und der Glaubensregel. Band III. Christiania : Malling. XVII, 514 S. (репринт: Bruxelles : Culture et Civilisation, 1964).

Caspari C. P., 1879. Alte und neue Quellen zur Geschichte des Taufsymbols und der Glaubensregel. Christiania : Mallingsche Buchdruckerei. $318 \mathrm{~S}$.

Chantraine P., 1932. Review of Müri 1931 // Bulletin de la Société linguistique de Paris. T. 33 / 3, Numéro 100. Р. 47-49. Электрон. текстовые дан. Режим доступа: http:/gallica.bnf.fr/ark:/12148/ bpt6k32174w/f359.image (21.07.2017).

Connolly R. H., 1946. St. Ambrose and the "Explanatio symboli" // The journal of theological studies. Vol. os-XLVII, iss. 187-188. P. 185-196. DOI: https:// doi.org/10.1093/jts/os-XLVII.187-188.185

Cullmann O., 1949. Die ersten christlichen Glaubensbekenntnisse / aus dem Französischen übersetzt von V.D.M. Hans Schaffert, zweite Auflage. Zürich ; Zollikon. 60 S. [Theologische Studien, Band 15].

Curtis W.A., 1911. A History of Creeds and Confessions of Faith in Christendom and Beyond. Edinburgh : Clark. XX, 502 p.

Denzinger H., 1880. Brunonis opera, post Reyseri et Cochlei curas recensuit H. Denzinger. Parisiis : Apud Mignem. 1460 col. [Patrologia Latina, t. 142].

Denzinger H., 2009. Kompendium der Glaubensbekenntnisse und kirchlichen Lehrentscheidungen / Enchiridion symbolorum definitionum et declarationum de rebus fidei et morum, verb., erw., ins Dt. übertr. und unter Mitarb. von H. Hoping hrsg. von P. Hünermann, CD-ROM-Ausg. Freiburg i. Br. et al. : Herder. XXXVI, $2020 \mathrm{~S}$.

Dörholt B., 1898. Das Taufsymbolum der alten Kirche nach Ursprung und Entwicklung, erster Teil: Geschichte der Symbolforschung. Paderborn : Druck und Verlag von Ferdinand Schöningh. VIII, 161 S. Электрон. текстовые дан. Режим доступа: https://sammlungen.ulb. uni-muenster.de/hd/content/titleinfo/3272274 (11.08.2017).
Evans G. R., 1979. The Academic Study of the Creeds in Twelfth-Century Schools // The Journal of Theological Studies. Vol. XXX, iss. 2. P. 463-480. DOI: https://doi.org/10.1093/jts/ XXX.2.463

Geldner F., 1968. Die deutschen Inkunabeldrucker. Ein Handbuch der deutschen Buchdrucker des XV. Jahrhunderts nach Druckorten. Band 1: Das deutsche Sprachgebiet. Stuttgart : Anton Hiersemann. $310 \mathrm{~S}$.

Ghellinck J. de, 1949. Patristique et Moyen Age. Études d'histoire littéraire et doctrinale. Tome I: Les recherches sur les origines du symbole des apôtres, nouvelle édition revue et considérablement augmentée. Gembloux et al. : Duculot et al. XII, 323 p. [Museum Lessianum, section historique, no. 6].

Goetz G., 1903. Beiträge zur Geschichte der lateinischen Studien im Mittelalter // Berichte über die Verhandlungen der Königlich Sächsischen Gesellschaft der Wissenschaften zu Leipzig. Philologisch-Historische Klasse. Band 55. S. 121-154.

Gordon J. D., 1965. The articles of the Creed and the Apostles // Speculum. Vol. 40, no. 4. P. 634-640.

Grimm H., 1967. Die Buchführer des deutschen Kulturbereichs und ihre Niederlassungsorte in der Zeitspanne 1490 bis um 1550 // Archiv für Geschichte des Buchwesens. Band 7. Sp. 1153-1772.

Hahn A., 1897. Bibliothek der Symbole und Glaubensregeln der alten Kirche, dritte vielfach veränderte und vermehrte Auflage. Breslau : Verlag von E. Morgenstern. XVI, $412 \mathrm{~S}$.

Hase O. von, 1967. Die Koberger. Eine Darstellung des buchhändlerischen Geschäftsbetriebes in der Zeit des Überganges vom Mittelalter zur Neuzeit, dritte Auflage. Amsterdam : Gérard Th. van Heusden-Wiesbaden : Breitkopf \& Härtel. 476 S. (Neudruck der zweiten, neugearbeiteten Auflage. Leipzig : Verlag Breitkopf \& Härtel, 1885. 440, CLIV S.)

Hauswald E., 2006. Pirmins Scarapsus - Einleitung und Edition : Dissertation zur Erlangung des akademischen Grades des Doktors der Philosophie (Dr. phil.). Universität Konstanz, Geisteswissenschaftliche Sektion, Fachbereich Geschichte und Soziologie. CXIV, 164 S. Электрон. текстовые дан. Режим доступа: https://kops.uni-konstanz.de/bitstream/ handle/123456789/11682/Diss_Hauswald. pdf?sequence=1 (11.08.2017).

Hitchkock F. R. Montgomery, 1946. The "Explanatio symboli ad initiandos" compared with Rufinus and Maximus of Turin // The Journal of Theological Studies. Vol. os-XLVII, iss. 185- 
186. P. 58-69. DOI: https://doi.org/10.1093/jts/ os-XLVII.185-186.58

Hübl A., 1899. Catalogus codicum manu scriptorum qui in bibliotheca monasterii B. M. V. ad Scotos Vindobonae servantur ex mandato reverendissimi domini abbatis Dris Ernesti Hauswirth edidit Dr. P. Albertus Hübl O. S. B. professor C. R. Gymnasii ad Scotos Vindobonae. Vindobonae et Lipsiae : In aedibus Guilelmi Braumüller. X, 610 p.

Isidorus episcopus Hispalensis, 1989. De ecclesiasticis officiis / Ch. M. Lawson (ed.). Turnholti : Typographi Brepols editores pontificii. CLXIII, 160 p. [Corpus Christianorum, Series latina, vol. 113].

Isidore of Seville, 2008. De ecclesiasticis officiis / translation and introduction by Thomas L. Knoebel. New York : Newman Press. 133 p. [Ancient Christian Writers, the works of the Fathers in translation, no. 61].

Jecker G., 1927. Die Heimat des H1. Pirmin des Apostels der Alamannen. Münster in Westfalen : Verlag der Aschendorffschen Verlagsbuchhandlung. XV, 192 S. [Beiträge zur Geschichte des alten Mönchtums und des Benediktinerordens, Heft 13]. Электрон. текстовые дан. Режим доступа: http://www.digishelf.de/objekt/ bsz435380362/1/\#topDocAnchor (11.08.2017).

Kattenbusch F., 1894. Das apostolische Symbol. Seine Entstehung, sein geschichtlicher Sinn, seine ursprüngliche Stellung im Kultus und in der Theologie der Kirche. Ein Beitrag zur Symbolik und Dogmengeschichte, erster Band: Die Grundgestalt des Taufsymbols. Leipzig : J. C. Hinrichs'sche Buchhandlung, Hinrichs'sche Buchhandlung. XIV, $410 \mathrm{~S}$.

Kattenbusch F., 1900. Das apostolische Symbol. Seine Entstehung, sein geschichtlicher Sinn, seine ursprüngliche Stellung im Kultus und in der Theologie der Kirche. Ein Beitrag zur Symbolik und Dogmengeschichte, zweiter Band: Verbreitung und Bedeutung des Taufsymbols. Leipzig : J.C. Hinrichs'sche Buchhandlung, Hinrichs'sche Buchhandlung. VIII, $1061 \mathrm{~S}$.

Kelly J. N. D., 1964. The Athanasian Creed. The Paddock Lectures for 1962-1963. London : Adam \& Charles Black. 140 p.

Kelly J. N. D., 1972. Early Christian Creeds. - 3rd edition - London ; New York : Continuum. XI, 446 p. [first edition London : Longmans, Green. 1960].

Kinzig W., Markschies Ch., Vinzent M., 1999. Tauffragen und Bekenntnis: Studien zur sogenannten "Traditio Apostolica", zu den "Interrogationes de fide" und zum "Römischen Glaubensbekenntnis". Berlin : de Gruyter. IX, 484 S. [Arbeiten zur Kirchengeschichte, Band 74].
Lietzmann H., 1962. Die Anfänge des Glaubensbekenntnisses // Id., Kleine Schriften, III: Studien zur Liturgie- und Symbolgeschichte, zur Wissenschaftsgeschichte, herausgegeben von der Kommission für spätantike Religionsgeschichte. Berlin : Akademie-Verlag S. 163-181 [Texte und Untersuchungen zur Geschichte der altchristlichen Literatur, $74=$ V. Reihe, 19; первоначально опубликовано в кн.: Festgabe von Fachgenossen und Freunden A. v. Harnack zum 70. Geburtstag dargebracht, Tübingen : Mohr, 1921, S. 226-242].

Mâle É., 1995. L'art religieux de la fin du moyen âge en France. Étude sur l'iconographie du moyen âge et sur ses sources d'inspiration. Septième édition, revue et corrigée, illustrée de 265 gravures. Paris : Colin. X, 570 р. (первое издание: Paris : Colin, 1908. XII, 554 p.).

Mathiesen R., 1981-1984-1985. An important early Slavic text of the Apostles' Creed // Byzantine Studies / Études Byzantines. No. 8, $11 \& 12$, p. 257-264 [= Essays in the area of Slavic languages, linguistics, and byzantology. A Festschrift in honor of Antonín Dostál on the occasion of his seventy-fifth birthday / ed. by Th.G. Winner with the assistance of J. Kasík].

Meier-Oeser S., 1998. Symbol (griech. $\sigma 0 ́ \mu \beta o \lambda o v ;$ lat. symbolum; engl. symbol; frz. symbole; ital. simbolo): I. Antike, Mittelalter, Neuzeit // Historisches Wörterbuch der Philosophie / hrsg. von J. Ritter und K. Gründer, völlig neubearbeitete Ausgabe des $<$ Wörterbuchs der philosophischen Begriffe> von R. Eisler. Bd. 10: St-T. Darmstadt : Wissenschaftliche Buchgesellschaft. 710-723 col. Электрон. текстовые дан. Режим доступа: https://www.uni-muenster.de/Leibniz/meieroeser/ Symbol.pdf (08.08.2017)

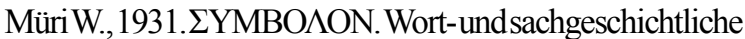
Studie. Beilage zum Jahresbericht über das Städtische Gymnasium in Bern. Bern : s. n., II, 46 S. (reprint: Müri W., 1976. Griechische Studien. Ausgewählte wort- und sachgeschichtliche Forschungen zur Antike, hrsg. von E. Vischer. Basel : Reinhardt. 1-44 S. [Schweizerische Beiträge zur Altertumswissenschaft, Band 14]).

Müri W., 1976. Griechische Studien. Ausgewählte wort- und sachgeschichtliche Forschungen zur Antike / W. Müri / Hrsg. von E. Vischer. Basel : Reinhardt, XI, 326 S. [Schweizerische Beiträge zur Altertumswissenschaft, Band 14].

Pelikan J., 2003. Credo. Historical and theological guide to Creeds and Confessions of faith in the Christian tradition. New Haven; London : Yale university press. $609 \mathrm{p}$.

Pelikan J., Hotchkiss V., 2003. Creeds and Confessions of faith in the Christian tradition. Vol. I, Part 
one: Rules of faith in the early Church, Part two: Eastern Orthodox affirmations of faith, Part three: Medieval Western statements of faith. New Haven ; London : Yale university press. XLVIII, $1031 \mathrm{p}$.

Pirmin, 2010. Scarapsus / Hrsg. v. E. Hauswald. Hahnsche Buchhandlung. CXXXIII, $181 \mathrm{~S}$. [Monumenta Germaniae Historica, Quellen zur Geistesgeschichte des Mittelalters, Band 25].

Podtergera I., 2016. Eurolatein und Russisch: Ein weiterer lexikalischer Europäismus im Russischen? // Osteuropakanal. Albert-Ludwigs-Universität Freiburg. (Dezember). Электрон. текстовые дан. Режим доступа: https:/www.osteuropakanal. uni-freiburg.de/Textinterview/eurolateinrussich (11.08.2017).

Powitz G., 1979. Textus cum commento // Codices manuscripti: Zeitschrift für Handschriftenkunde. Band 5, Haft 3. S. 80-89. Электрон. текстовые дан. Режим доступа: http://publikationen. ub.uni-frankfurt.de/frontdoor/index/index/ docId/507 (25.08.2017); то же в: Powitz G., 2005. Handschriften und frühe Drucke. Ausgewählte Aufsätze zur mittelalterlichen Buch- und Bibliotheksgeschichte. Frankfurt am Main : Klostermann. S. 57-81. [Frankfurter Bibliotheksschriften, Band 12].

Powitz G., 1988. Das "Catholicon" in buch- und textgeschichtlicher Sicht // Wolfenbütteler Notizen zur Buchgeschichte. No. 13. Р. 125-137. Электрон. текстовые дан. Режим доступа: http://publikationen.ub.unifrankfurt.de/frontdoor/index/index/docId/890 (25.08.2017); то же в: Powitz G., 2005. Handschriften und frühe Drucke. Ausgewählte Aufsätze zur mittelalterlichen Buch- und Bibliotheksgeschichte. Frankfurt am Main : Klostermann. S. 113-133. [Frankfurter Bibliotheksschriften, Band 12].

Probst F., 1886. Geschichte der katholischen Katechese. Breslau : Goerlich. XII, 192 S.

Proctor R., 1960. An index to the early printed books in the British Museum, from the invention of printing to the year 1500 . With notes of those in the Bodleian Library. London : The Holland Press. 987 p.

Rationale, 1995. Guillelmi Duranti Rationale divinorum officiorum I-IV / ediderunt A. Davril \& T. M. Thibodeau. Turnholti : Typographi Brepols editores pontificii. XXIV, 160 p. [Corpus Christianorum, Continautio mediaeualis, vol. 140].

Rationale, 2013. William Durand, Rationale, Book IV: On the mass and each action pertaining to it / introduction, translation and notes by T. M. Thibodeau. Turnhout : Brepols. 525 p. [Corpus Christianorum in translation, vol. 14].
Riedl G., 2004. Hermeneutische Grundstrukturen frühchristlicher Bekenntnisbildung. Berlin ; New York : de Gruyter. 536 S. [Theologische Bibliothek Töpelmann. Band 123].

Rufinus, 1955. A commentary on the Apostles' Creed / translated and annotated by J. N. D. Kelly, Westminster, Maryland ; London : NewmanLongmans, Green and Co. VIII, 166 p. [Ancient Christian writers, The works of the Fathers in translation, no. 20].

Sanday W., 1899. Recent research on the origin of the Creed// The Journal of Theological Studies. Vol. os-I, iss. 1. P. 3-22. DOI: https://doi.org/10.1093/ jts/os-I.1.3

Sautel J.-H., 1999. Essai de terminologie de la mise en page des manuscrits à commentaire // Gazette du livre médiéval. Vol. 35, num. 1. Р. 17-31. Электрон. текстовые дан. Режим доступа: http:// www.persee.fr/doc/galim_0753-5015_1999_ num $35 \quad 1 \quad 1456$ (25.08.2017).

Schaff Ph., $18 \overline{7} 7$. The Creeds of Christendom, with a history and critical notes. In three volumes. Vol. I: The history of Creeds. New York : Harper \& Brothers. XIII, $941 \mathrm{p}$.

Schaff Ph., 1878. The Creeds of Christendom, with a history and critical notes. In three volumes. Vol. I: The Greek and Latin Creeds, with translations. New York : Harper \& Brothers. 559 p.

Scheele P.-W., 1990. Bruno von Würzburg: Freund Gottes und der Welt. Zweite Auflage. Würzburg : Echter. $190 \mathrm{~S}$.

Schlesinger M., 1912. Geschichte des Symbols. Ein Versuch. Berlin : Simion NF. 474 S.

Schramm A., 1923. Anton Koberger // Die Zeugkiste: Kurioser Almanach für Buchdrucker, Buchgewerbler und Buchfreunde / hrsg. von Rudolf Engel. Leipzig : J. Mäser. P. 13-20.

Specht F.A., 1885. Geschichte des Unterrichtswesens in Deutschland: von den ältesten Zeiten bis zur Mitte des dreizehnten Jahrhunderts. Stuttgart : Verlag der F. G. Cotta'schen Buchhandlung. $411 \mathrm{~S}$.

Stegmüller F., 1950. Repertorium biblicum medii aevi, collegit disposuit edidit Fridericus Stegmüller in Universitate Friburgensi Brisg. Sacrae Theologiae professor ordinarius publicus. Tomus 2: Commentaria (Auctores A-G). Matriti : Consejo superior de investigaciones científicas, Instituto Francisco Suárez. 439 p.

Suto T., 2012. Boethius on mind, grammar and logic: a study of Boethius' commentaries on Peri hermeneias. Leiden ; Boston : Brill. XXIII, 296 p. [Philosophia antiqua, A series of studies on ancient philosophy. Vol. 127].

Swainson Ch. A., 1875. The Nicene and Apostles' Creeds. Their Literary History; together with an Account of the Growth and Reception of the 
Sermon on the Faith, commonly called "The Creed of St Athanasius". London : J. Murray. $\mathrm{XV}, 543 \mathrm{p}$.

Thomas Aquinas, 1933. Scriptum super sententiis Magistri Petri Lombardi / recognovit atque iterum edidit R. P. Maria Fabianus Moos, O. P. Tomus III. Parisiis : Sumptibus P. Lethielleux. XV, $1358 \mathrm{p}$.

Tomelleri V. S., 2004. Il Salterio commentato di Brunone di Würzburg in area slavo-orientale. Fra traduzione e tradizione (Con un'appendice di testi). München : Verlag Otto Sagner. XVII, 343 S. [Slavistische Beiträge. Band 430].

Tomelleri V. S., 2005. Zur kyrillischen Wiedergabe des Lateinischen im Kreis um den Novgoroder Bischof Gennadij // Die Welt der Slaven. Band. L, Heft 1. S. 23-32.

Tomelleri V. S., 2008. Kritisch-historische Ausgabe der Tolkovaja Psaltir' Brunona (1535) // Studi Slavistici. Iss. V. P. 31-48. Электрон. текстовые дан. Режим доступа: http://www. fupress.net/index.php/ss/article/view/2690/2431 (10.08.2017).

Troelstra A., 1903. Stof en methode der catechese in Nederland vóór de reformatie. Groningen : Wolters. XII, $356 \mathrm{p}$.

Tyranni Rufini, 1961. Expositio symboli // Tyranni R. Opera / recognovit M. Simonetti. Turnholti : Typographi Brepols editores pontificii. P. 125182 [Corpus Christianorum, Series latina, no. 20].

Universitätsbibliothek Wien, 1996. Universitätsbibliothek Wien. Katalog der Inkunabeln / zusammengestellt von H. Alker, 2, durchges. und erw. Aufl. / L. Cornaro (hrsg.). Wien : Universitätsbibliothek. XV, 279, XLV S.

Vinzent M., 2006. Der Ursprung des Apostolikums im Urteil der kritischen Forschung. Göttingen : Vandenhoeck \& Ruprecht. 480 S. [Forschungen zur Kirchen- und Dogmengeschichte. Band 89].

Vouilléme E., 1922. Die deutschen Drucker des fünfzehnten Jahrhunderts, zweite Auflage. Berlin : Druck und Verlag der Reichsdruckerei. XVI, 176 S.

Westra L. H., 2002. The Apostles' Creed. Origin, history and some early commentaries. Turnhout : Brepols. 612 p. [Instrumenta patristica et mediaevalia. Vol. 43].

Westra L. H., 2010a. How did Symbolum came to mean 'Creed'? // Studia Patristica. Vol. 45. P. 85-91 [= Papers presented at the Fifteenth International Conference on patristic studies held in Oxford 2007 (Ascetica, liturgica, orientalia, critica et philologica, the first two centuries) / ed. by J. Baun et al. - Leuven et al. : Peeters, 2010].

Westra L. H., 2010b. Cyprian, the Mystery Religions and the Apostles' Creed - An Unexpected Link
// Cyprian of Carthage. Studies in his life, language, and thought / ed. by H. Bakker, P. van Geest, H. van Loon. Leuven et al. : Peeters. P. $115-125$.

Wiegand F., 1899. Die Stellung des apostolischen Symbols im kirchlichen Leben des Mittelalters. Teil. I: Symbol und Katechumenat. Leipzig : Dieterich'sche Verlags-Buchhandlung Theodor Weicher. 364 s. [Studien zur Geschichte der Theologie und der Kirche. Band. 4, Heft 2]. Wiegand F., 1904. Das apostolische Symbol im Mittelalter. Eine Skizze. Giessen : Ricker'sche Verlagsbuchhandlung (Töpelmann). $52 \mathrm{~S}$. [Vorträge der theologischen Konferenz zu Giessen, 21].

Wimmer E., 1990. Die russisch-kirchenslavische Version von Maximilian Transylvans De Moluccis insulis...epistola und ihr Autor // Zeitschrift für slavische Philologie. Band 50. S. 51-66.

Zwierlein O., 2002. "Interpretation" in Antike und Mittelalter // Der Kommentar in Antike und Mittelalter: Beiträge zu seiner Erforschung / W. Geerlings, Ch. Schulze (hrsg.). Leiden ; Boston ; Köln : Brill. S. 79-101 [Clavis Commentariorum Antiquitatis et Medii Aevi. Band 2].

\section{REFERENCES}

Gezen A.M., 1884. Essays and notes from the field of philology, history and philosophy. Iss. 1. History of the Slavic translation of the Creeds. Critical-paleographic notes with four pictures. Sankt-Petersburg, Tipografiya Imperatorskoy Akademii Nauk. 128 p. (in Russian).

The catechism of the Catholic Church. A Compendium. Moscow, Kul'turnyj centr «Duhovnaya biblioteka», 2007. 216 p. (in Russian).

Kuzenkov P.V., 2014. Christian chronological systems. History of chronology in the patristic and Eastern Christian traditions. Moscow, Russkiy izdatel'skiy centr. 992 p. (in Russian).

Podtergera I.A., Tomelleri V.S., 2009, Catholicus: гвБорьнын - капдолнческїн - Прақославьнын (from the history of the term). Part 1. Russkiy yazyk $v$ nauchnom osveshchenii, no. 1 (17), pp. 44-108. URL: http://www.ruslang.ru/doc/rjano17.pdf (24.08.2017). (in Russian).

The Homilies of Gavriil Buzhinsky (1717-1727). Historical and literary material from the conversion time, published according to the manuscripts of the Moscow Theological Academy by Evgeniy Petukhov]. Yur'ev, Tipografiya Mattisen, 1901. XII, $676 \mathrm{p}$. (in Russian). 
Tomelleri V.S., 2013. On some syntactic features of Bruno's commented Psalter (1535). Absolute dative, infinitive and participle constructions, gerund and gerundive. Lingvisticheskoye istochnikovedenie i istoriya russkogo yazyka 20122013: Sb. statey. Moscow, Drevlehranilishche, 2013, pp. 196-225. URL: http://www.ruslang. ru/doc/lingistoch/2012-2013/10-tomelleri.pdf (08.08.2017). (in Russian).

Tomelleri V.S., 2016. Some observations on the terminology of translated works. Slavonic equivalents for the term "catholicus" in translations from Latin performed in Novgorod the Great. Rossica Olomucensia, vol. LV, num. 2, pp. 5-42. URL: http://www.rusistika. upol.cz/fileadmin/ksl/rusistika/rossica/Rossica Olomucensia_2016_2.pdf (24.08.2017). (in Russian).

Tomelleri V.S., 2017. The Pseudo-Athanasian Creed (Symbolum Athanasii) in the Church Slavonic translation by Dmitry Gerasimov (Introduction. Interlinear edition). Latinitas in the Slavonic World. Nine case studies, ed. by V.S. Tomelleri, I.V. Verner with the collaboration of A. Lukianowicz. Frankfurt am Main et al., Lang, S. 113-171 [Specimina Philologiae Slavicae, Bd 192]. (in Russian).

Uspenskiy B.A., 2002. History of the Russian literary language (11th-17th centuries), third edition, corrected and augmented. Moscow, Aspekt Press. 558 p. (in Russian).

Ashwin-Siejkowski P., 2009. The Apostles'Creed and its early christian context. London, New York, T\&T Clark International. 197 p.

Baier J., 1893. Der heilige Bruno, Bischof von Würzburg, als Katechet: Ein Beitrag zur deutschen Schlugeschichte. Würzburg, Godel. $168 \mathrm{~S}$.

Bäumer S., 1893.Das apostolische Glaubensbekenntnis. Seine Geschichte und sein Inhalt. Mainz, Kirchheim. VIII, $240 \mathrm{~S}$.

Bibliotheca sacra, 1785. Bibliotheca sacra post cl. cl. v.v. Jacobi Le Long et C.F. Boerneri iteratas curas ordine disposita, emendata suppleta, continuata ab Andrea Gottlieb Masch sereniss. duci regn. megapol. a sacris et consil. eccles., et ecclesiar. circuli Stargard. et ducatus Raceburg. superattendente, partis secundae de versionibus librorum sacrorum volumen tertium de versionibus latinis. Halae, J. Jac. Gebaueri. XX, 352 S. URL: http://digitale.bibliothek. uni-halle.de/vd18/content/titleinfo/3142350 (24.08.2017).

Blume C., 1893. Das apostolische Glaubensbekenntnis. Eine apologetisch-geschichtliche Studie, mit Rücksicht aufden ,, Kampf um das Apostolicum “.
Freiburg im Breisgau, Herder'sche Verlagshandlung. XVI, $304 \mathrm{~S}$.

Boretius A., 1883. Capitularia regum Francorum, denuo edidit Alfredus Boretius, tomus primus. Hannoverae, Impensis bibliopolii Hahniani. 462 S. URL: http://daten.digitale-sammlungen.

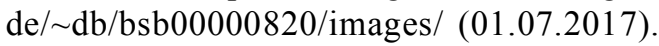

Brady M.T., 1957. The Apostles and the Creed in manuscripts of The Pore Caitif. Speculum, vol. 32, no. 2, pp. 323-325.

Bühler C.F., 1953. The Apostles and the Creed. Speculum, vol. 28, no. 2, pp. 335-339 (reissue: Bühler C.F. Early Books and Manuscripts. Forty Years of Research. New York, The Grolier Club, The Pierpont Morgan Library, 1973, pp. 484-489).

Burn A.E., 1896. The Athanasian Creed and its early commentaries. Cambridge, University Press. XCIX, 68 p. [Texts and studies, Contributions to biblical and patristic literature, vol. IV, no. 1].

Burn A.E., 1899. Neue Texte zur Geschichte des apostolischen Symbols. Zeitschrift für Kirchengeschichte, Band. 18, Heft. 2, S. 179-190.

Carpenter H.J., 1942. "Symbolum" as a title of the Creed. The Journal of Theological Studies, vol. os-XLIII, iss. 169-170, pp. 1-11. DOI: https:// doi.org/10.1093/jts/os-XLIII.169-170.1

Caspari C.P., 1866. Ungedruckte, unbeachtete und wenig beachtete Quellen zur Geschichte des Taufsymbols und der Glaubensregel. Band I. Christiania, Malling. VIII, 305 S. (reprint: Bruxelles, Culture et Civilisation, 1964).

Caspari C.P., 1869. Ungedruckte, unbeachtete und wenig beachtete Quellen zur Geschichte des Taufsymbols und der Glaubensregel. Band II. Christiania, Malling. 305 S. (reprint: Bruxelles, Culture et Civilisation, 1964).

Caspari C.P., 1875. Ungedruckte, unbeachtete und wenig beachtete Quellen zur Geschichte des Taufsymbols und der Glaubensrege. Band III. Christiania, Malling. XVII, 514 S. (reprint: Bruxelles, Culture et Civilisation, 1964).

Caspari C.P., 1879. Alte und neue Quellen zur Geschichte des Taufsymbols und der Glaubensregel. Christiania, Mallingsche Buchdruckerei. 318 S.

Chantraine P., 1932. Review of Müri 1931. Bulletin de la Société linguistique de Paris. T. 33 / 3, Numéro 100, pp. 47-49. URL: http://gallica. bnf.fr/ark:/12148/bpt6k32174w/f359.image (21.07.2017).

Connolly R.H., 1946. St. Ambrose and the "Explanatio symboli". The journal of theological studies, vol. os-XLVII, iss. 187-188, pp. 185-196. DOI: https://doi.org/10.1093/jts/os-XLVII. 187-188.185

Cullmann O., 1949. Die ersten christlichen Glaubensbekenntnisse, aus dem Französischen 
übersetzt von V.D.M. Hans Schaffert, zweite Auflage. Zürich, Zollikon. 60 S. [Theologische Studien, Band 15].

Curtis W.A., 1911. A History of Creeds and Confessions of Faith in Christendom and Beyond. Edinburgh, Clark. XX, 502 p.

Denzinger H., 1880. Brunonis opera, post Reyseri et Cochlei curas recensuit H. Denzinger. Parisiis, Apud Mignem. 1460 col. [Patrologia Latina, t. 142].

Denzinger H., 2009. Kompendium der Glaubensbekenntnisse und kirchlichen Lehrentscheidungen / Enchiridion symbolorum definitionum et declarationum de rebus fidei et morum, verb., erw., ins Dt. übertr. und unter Mitarb. von H. Hoping hrsg. von P. Hünermann, CD-ROM-Ausg. Freiburg i. Br. et al. : Herder. XXXVI, $2020 \mathrm{~S}$.

Dörholt B., 1898. Das Taufsymbolum der alten Kirche nach Ursprung und Entwicklung, erster Teil: Geschichte der Symbolforschung. Paderborn, Druck und Verlag von Ferdinand Schöningh. VIII, 161 S. URL: https://sammlungen.ulb. uni-muenster.de/hd/content/titleinfo/3272274 (11.08.2017).

Evans G.R., 1979. The Academic Study of the Creeds in Twelfth-Century Schools. The Journal of Theological Studies, vol. XXX, iss. 2, pp. 463480. DOI: https://doi.org/10.1093/jts/XXX.2.463

Geldner F., 1968. Die deutschen Inkunabeldrucker. Ein Handbuch der deutschen Buchdrucker des $X V$. Jahrhunderts nach Druckorten. Band 1: Das deutsche Sprachgebiet. Stuttgart, Anton Hiersemann. $310 \mathrm{~S}$.

Ghellinck J. de., 1949. Patristique et Moyen Age. Études d'histoire littéraire et doctrinale. Tome I: Les recherches sur les origines du symbole des apôtres, nouvelle édition revue et considérablement augmentée. Gembloux et al., Duculot et al. XII, 323 p. [Museum Lessianum, section historique, no. 6].

Goetz G., 1903. Beiträge zur Geschichte der lateinischen Studien im Mittelalter. Berichte über die Verhandlungen der Königlich Sächsischen Gesellschaft der Wissenschaften zu Leipzig. Philologisch-Historische Klasse, Band. 55, S. 121-154.

Gordon J.D., 1965. The articles of the Creed and the Apostles. Speculum, vol. 40, no. 4, pp. 634-640.

Grimm H., 1967. Die Buchführer des deutschen Kulturbereichs und ihre Niederlassungsorte in der Zeitspanne 1490 bis um 1550. Archiv für Geschichte des Buchwesens, Band 7, Sp. 1153-1772.

Hahn A., 1897. Bibliothek der Symbole und Glaubensregeln der alten Kirche, dritte vielfach veränderte und vermehrte Auflage. Breslau, Verlag von E. Morgenstern. xvi, $412 \mathrm{~S}$.
Hase O. von, 1967. Die Koberger. Eine Darstellung des buchhändlerischen Geschäftsbetriebes in der Zeit des Überganges vom Mittelalter zur Neuzeit, dritte Auflage. Amsterdam, Gérard Th. van Heusden-Wiesbaden, Breitkopf \& Härtel. 476 S. (Neudruck der zweiten, neugearbeiteten Auflage. Leipzig, Verlag Breitkopf \& Härtel, 1885. 440, CLIV S.)

Hauswald E., 2006. Pirmins Scarapsus - Einleitung und Edition. Dissertation zur Erlangung des akademischen Grades des Doktors der Philosophie (Dr. phil.). Universität Konstanz, Geisteswissenschaftliche Sektion, Fachbereich Geschichte und Soziologie. cxiv, $164 \mathrm{~S}$. URL: https://kops.uni-konstanz.de/bitstream/ handle/123456789/11682/Diss_Hauswald. pdf? sequence $=1$ (11.08.2017).

Hitchkock F.R. Montgomery, 1946. The "Explanatio symboli ad initiandos" compared with Rufinus and Maximus of Turin. The Journal of Theological Studies, vol. os-XLVII, iss. 185186, pp. 58-69. DOI: https://doi.org/10.1093/ jts/os-XLVII.185-186.58

Hübl A., 1899. Catalogus codicum manu scriptorum qui in bibliotheca monasterii B. M.V. ad Scotos Vindobonae servantur ex mandato reverendissimi domini abbatis Dris Ernesti Hauswirth edidit Dr. P. Albertus Hübl O. S. B. professor C. R. Gymnasii ad Scotos Vindobonae. Vindobonae et Lipsiae, In aedibus Guilelmi Braumüller. X, 610 p.

Isidorus episcopus Hispalensis, 1989. De ecclesiasticis officiis, Ch. M. Lawson (ed.). Turnholti, Typographi Brepols editores pontificii. CLXIII+ 160 p. [Corpus Christianorum, Series latina, vol. 113].

Isidore of Seville, 2008. De ecclesiasticis officiis, translation and introduction by Thomas L. Knoebel. New York : Newman Press. 133 p. [Ancient Christian Writers, the works of the Fathers in translation, no. 61].

Jecker G., 1927. Die Heimat des Hl. Pirmin des Apostels der Alamannen. Münster in Westfalen, Verlag der Aschendorffschen Verlagsbuchhandlung. XV, 192 S. [Beiträge zur Geschichte des alten Mönchtums und des Benediktinerordens, Heft 13]. URL: http://www.digishelf.de/objekt/ bsz435380362/1/\#topDocAnchor (11.08.2017).

Kattenbusch F., 1894. Das apostolische Symbol. Seine Entstehung, sein geschichtlicher Sinn, seine ursprüngliche Stellung im Kultus und in der Theologie der Kirche. Ein Beitrag zur Symbolik und Dogmengeschichte, erster Band: Die Grundgestalt des Taufsymbols. Leipzig, J. C. Hinrichs'sche Buchhandlung, Hinrichs'sche Buchhandlung. XIV, $410 \mathrm{~S}$. 
Kattenbusch F., 1900. Das apostolische Symbol. Seine Entstehung, sein geschichtlicher Sinn, seine ursprüngliche Stellung im Kultus und in der Theologie der Kirche. Ein Beitrag zur Symbolik und Dogmengeschichte, zweiter Band: Verbreitung und Bedeutung des Taufsymbols. Leipzig, J.C. Hinrichs'sche Buchhandlung, Hinrichs'sche Buchhandlung. VIII, $1061 \mathrm{~S}$.

Kelly J.N.D., 1964. The Athanasian Creed. The Paddock Lectures for 1962-1963. London, Adam \& Charles Black. 140 p.

Kelly J.N.D., 1972. Early Christian Creeds, 3rd edition, London, New York, Continuum. XI, 446 p. [first edition London, Longmans, Green 1960].

Kinzig W., Markschies Ch. \& Vinzent M., 1999. Tauffragen und Bekenntnis: Studien zur sogenannten "Traditio Apostolica”, zu den "Interrogationes de fide" und zum "Römischen Glaubensbekenntnis”. Berlin, de Gruyter. IX, 484 S. [Arbeiten zur Kirchengeschichte, Band 74].

Lietzmann H., 1962. Die Anfänge des Glaubensbekenntnisses. Id., Kleine Schriften, III: Studien zur Liturgie- und Symbolgeschichte, zur Wissenschaftsgeschichte, herausgegeben von der Kommission für spätantike Religionsgeschichte. Berlin : Akademie-Verlag S. 163-181 [Texte und Untersuchungen zur Geschichte der altchristlichen Literatur, $74=\mathrm{V}$. Reihe, 19; first edition: Festgabe von Fachgenossen und Freunden A. v. Harnack zum 70. Geburtstag dargebracht, Tübingen, Mohr, 1921, S. 226-242].

Mâle É., 1995. L'art religieux de la fin du moyen âge en France. Étude sur l'iconographie du moyen âge et sur ses sources d'inspiration, septième édition, revue et corrigée, illustrée de 265 gravures. Paris, Colin. X, 570 p. [first edition:Paris : Colin, 1908. XII, 554 p.].

Mathiesen R., 1981-1984-1985. An important early Slavic text of the Apostles' Creed. Byzantine Studies / Études Byzantines, no. 8, $11 \& 12$, pp. $257-264$ [= Essays in the area of Slavic languages, linguistics, and byzantology. A Festschrift in honor of Antonín Dostál on the occasion of his seventy-fifth birthday, ed. by Th.G. Winner with the assistance of J. Kasík].

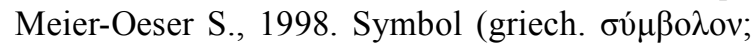
lat. symbolum; engl. symbol; frz. symbole; ital. simbolo): I. Antike, Mittelalter, Neuzeit. Historisches Wörterbuch der Philosophie, hrsg. von J. Ritter und K. Gründer, völlig neubearbeitete Ausgabe des <Wörterbuchs der philosophischen Begriffe $>$ von R. Eisler, Bd. 10: St-T. Darmstadt, Wissenschaftliche Buchgesellschaft, 710-723 col. URL: https:// www.uni-muenster.de/Leibniz/meieroeser/ Symbol.pdf (08.08.2017)

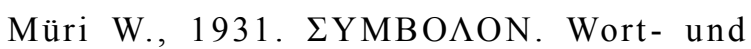
sachgeschichtliche Studie. Beilage zum Jahresbericht über das Städtische Gymnasium in Bern. Bern, s. n. 46 S.; (reprint: Müri W., 1976. Griechische Studien. Ausgewählte wort- und sachgeschichtliche Forschungen zur Antike, Hrsg. von E. Vischer. Basel : Reinhardt. 1-44 S. [Schweizerische Beiträge zur Altertumswissenschaft, Band 14]).

Müri W., 1976. Griechische Studien. Ausgewählte wort- und sachgeschichtliche Forschungen zur Antike, hrsg. von E. Vischer. Basel, Reinhardt. XI, 326 S. [Schweizerische Beiträge zur Altertumswissenschaft, Band 14].

Pelikan J., 2003. Credo. Historical and theological guide to Creeds and Confessions of faith in the Christian tradition. New Haven, London, Yale university press. $609 \mathrm{p}$.

Pelikan J. \& Hotchkiss V., 2003. Creeds and Confessions of faith in the Christian tradition. Vol. I, Part one: Rules of faith in the early Church, Part two: Eastern Orthodox affirmations of faith, Part three: Medieval Western statements of faith. New Haven-London, Yale university press. XLVIII, $1031 \mathrm{p}$.

Pirmin, 2010. Scarapsus, hrsg. v. E. Hauswald. Hahnsche Buchhandlung. CXXXIII, $181 \mathrm{~S}$. [Monumenta Germaniae Historica, Quellen zur Geistesgeschichte des Mittelalters, Band 25].

Podtergera I., 2016. Eurolatein und Russisch: Ein weiterer lexikalischer Europäismus im Russischen? Osteuropakanal. Albert-LudwigsUniversität Freiburg. (Dezember). URL: https:/www.osteuropakanal.uni-freiburg.de/ Textinterview/eurolateinrussich (11.08.2017).

Powitz G., 1979. Textus cum commento. Codices manuscripti: Zeitschrift für Handschriftenkunde, Band 5, Haft 3, S. 80-89. Available at: http:// publikationen.ub.uni-frankfurt.de/frontdoor/ index/index/docId/507 (25.08.2017); reprint: PowitzG., 2005. Handschriften und frühe Drucke. Ausgewählte Aufsätze zur mittelalterlichen Buch- und Bibliotheksgeschichte. Frankfurt am Main, Klostermann, S. 57-81 [Frankfurter Bibliotheksschriften, Band 12].

Powitz G., 1988. Das "Catholicon" in buch- und textgeschichtlicher Sicht. Wolfenbütteler Notizen zur Buchgeschichte, no. 13, pp. 125-137. Available at: http://publikationen. ub.uni-frankfurt.de/frontdoor/index/index/ docId/890 (25.08.2017); reprint: Powitz G., 2005. Handschriften und frühe Drucke. Ausgewählte Aufsätze zur mittelalterlichen Buch- und Bibliotheksgeschichte. Frankfurt am Main, Klostermann, S. 113-133. [Frankfurter Bibliotheksschriften, Band 12]. 
Probst F., 1886. Geschichte der katholischen Katechese. Breslau, Goerlich. XII, 192 S.

Proctor R., 1960. An index to the early printed books in the British Museum, from the invention of printing to the year 1500. With notes of those in the Bodleian Library. London, The Holland Press. 987 p.

Rationale, 1995. Guillelmi Duranti Rationale divinorum officiorum $I-I V$, ediderunt A. Davril \& T.M. Thibode au. Turnholti, Typographi Brepols editores pontificii. XXIV, 160 p. [Corpus Christianorum, Continautio mediaeualis, vol. 140].

Rationale, 2013. William Durand, Rationale, Book IV: On the mass and each action pertaining to it, introduction, translation and notes by T. M. Thibodeau. Turnhout, Brepols. 525 p. [Corpus Christianorum in translation, vol. 14].

Riedl G., 2004. Hermeneutische Grundstrukturen frühchristlicher Bekenntnisbildung. Berlin, New York, de Gruyter. 536 S. [Theologische Bibliothek Töpelmann. Band 123].

Rufinus, 1955. A commentary on the Apostles' Creed, translated and annotated by J.N.D. Kelly, Westminster, Maryland-London, NewmanLongmans, Green and Co. VIII, 166 p. [Ancient Christian writers, The works of the Fathers in translation, no. 20].

Sanday W., 1899. Recent research on the origin of the Creed. The Journal of theological studies, vol. os-I, iss. 1, pp. 3-22. DOI: https://doi. org/10.1093/jts/os-I.1.3

Sautel J.-H., 1999. Essai de terminologie de la mise en page des manuscrits à commentaire. Gazette du livre médiéval, vol. 35, num. 1, pp. 17-31. Available at: http://www.persee.fr/ doc/galim_0753-5015_1999_num_35_1_1456 (25.08.2017).

Schaff Ph., 1877. The Creeds of Christendom, with a history and critical notes. In three volumes. Vol. I: The history of Creeds. New York, Harper \& Brothers. XIII, $941 \mathrm{p}$.

Schaff Ph., 1878. The Creeds of Christendom, with a history and critical notes. In three volumes. Vol. II: The Greek and Latin Creeds, with translations. New York, Harper \& Brothers. 559 p.

Scheele P.-W., 1990. Bruno von Würzburg: Freund Gottes und der Welt, zweite Auflage. Würzburg, Echter. $190 \mathrm{~S}$

Schlesinger M., 1912. Geschichte des Symbols. Ein Versuch. Berlin, Simion NF. $474 \mathrm{~S}$.

Schramm A., 1923. Anton Koberger. Die Zeugkiste: Kurioser Almanach für Buchdrucker, Buchgewerbler und Buchfreunde, hrsg. von Rudolf Engel. Leipzig, J. Mäser, pp. 13-20.

Specht F. A., 1885. Geschichte des Unterrichtswesens in Deutschland: von den ältesten Zeiten bis zur Mitte des dreizehnten Jahrhunderts. Stuttgart, Verlag der F. G. Cotta'schen Buchhandlung. $411 \mathrm{~S}$.

Stegmüller F., 1950. Repertorium biblicum medii aevi, collegit disposuit edidit Fridericus Stegmüller in Universitate Friburgensi Brisg. Sacrae Theologiae professor ordinarius publicus, Tomus 2: Commentaria (Auctores A-G). Matrit, Consejo superior de investigaciones científicas, Instituto Francisco Suárez. 439 p.

Suto T., 2012. Boethius on mind, grammar and logic: a study of Boethius' commentaries on Peri hermeneias. Leiden, Boston, Brill. XXIII, 296 p. [Philosophia antiqua, A series of studies on ancient philosophy. Vol. 127].

Swainson Ch. A., 1875. The Nicene and Apostles'Creeds: their Literary History, together with an Account of the Growth and Reception of the Sermon on the Faith, commonly called "The Creed of St Athanasius". London, J. Murray. XV, 543 p.

Thomas Aquinas, 1933. Scriptum super sententiis Magistri Petri Lombardi, recognovit atque iterum edidit R.P. Maria Fabianus Moos, O.P. Tomus III. Parisiis, Sumptibus P. Lethielleux. XV, 1358 p.

Tomelleri V.S., 2004. Il Salterio commentato di Brunone di Würzburg in area slavo-orientale. Fra traduzione e tradizione (Con un'appendice di testi). München, Verlag Otto Sagner. XVII, 343 p. [Slavistische Beiträge. Band 430].

Tomelleri V.S., 2005. Zur kyrillischen Wiedergabe des Lateinischen im Kreis um den Novgoroder Bischof Gennadij. Die Welt der Slaven, Band. L, Heft 1, S. 23-32.

Tomelleri V.S., 2008. Kritisch-historische Ausgabe der Tolkovaja Psaltir' Brunona (1535). Studi Slavistici, iss. V, pp. 31-48. Available at: http:/www.fupress.net/index.php/ss/article/ view/2690/2431 (10.08.2017).

Troelstra A., 1903. Stof en methode der catechese in Nederland vóór de reformatie. Groningen, Wolters. XII, 356 p.

Tyranni Rufini, 1961. Expositio symboli. Tyranni $R$. Opera, recognovit M. Simonetti. Turnholti, Typographi Brepols editores pontificii, pp. 125182 [Corpus Christianorum, Series latina, no. 20].

Universitätsbibliothek Wien, 1996. Universitätsbibliothek Wien. Katalog der Inkunabeln, zusammengestellt von $\mathrm{H}$. Alker, 2, durchges. und erw. Aufl., L. Cornaro (hrsg.). Wien, Universitätsbibliothek. XV, 279, XLV S.

Vinzent M., 2006. Der Ursprung des Apostolikums im Urteil der kritischen Forschung. Göttingen, Vandenhoeck \& Ruprecht. 480 S. [Forschungen zur Kirchen- und Dogmengeschichte. Band 89].

Vouilléme E., 1922. Die deutschen Drucker des fünfzehnten Jahrhunderts, zweite Auflage. Berlin, Druckund Verlag der Reichsdruckerei. XVI, 176S. 
Westra L.H., 2002. The Apostles' Creed. Origin, history and some early commentaries. Turnhout, Brepols. 612 p. [Instrumenta patristica et mediaevalia. Vol. 43].

Westra L.H., 2010a. How did Symbolum came to mean 'Creed'? Studia Patristica, vol. 45, pp. 85-91 [= Papers presented at the Fifteenth International Conference on patristic studies held in Oxford 2007 (Ascetica, liturgica, orientalia, critica et philologica, the first two centuries), ed. by J. Baun et al., Leuven et al., Peeters, 2010].

Westra L.H., 2010b. Cyprian, the Mystery Religions and the Apostles' Creed - An Unexpected Link. Cyprian of Carthage. Studies in his life, language, and thought, ed. by H. Bakker, P. van Geest, H. van Loon. Leuven et al., Peeters, pp. 115-125.

Wiegand F., 1899. Die Stellung des apostolischen Symbols im kirchlichen Leben des Mittelalters. Teil. I: Symbol und Katechumenat. Leipzig,
Dieterich'sche Verlags-Buchhandlung Theodor Weicher. 364 s. [Studien zur Geschichte der Theologie und der Kirche. Band. 4, Heft 2].

Wiegand F., 1904. Das apostolische Symbol im Mittelalter. Eine Skizze. Giessen, Ricker'sche Verlagsbuchhandlung (Töpelmann). $52 \mathrm{~S}$. [Vorträge der theologischen Konferenz zu Giessen, 21].

Wimmer E., 1990. Die russisch-kirchenslavische Version von Maximilian Transylvans De Moluccis insulis...epistola und ihr Autor. Zeitschrift für slavische Philologie, Band 50, S. 51-66.

Zwierlein O., 2002. "Interpretation" in Antike und Mittelalter. Der Kommentar in Antike und Mittelalter: Beiträge zu seiner Erforschung, W. Geerlings, Ch. Schulze (hrsg.). Leiden-BostonKöln, Brill, S. 79-101 [Clavis Commentariorum Antiquitatis et Medii Aevi. Band 2].

\section{Information about the Author}

Vittorio Springfield Tomelleri, Dr. phil., Professor of Slavonic Philology, Macerata State University, Department of Humanities, Via Illuminati 4, 62100 Macerata, Italia, vittorio.tomelleri@unimc.it, http:// orcid.org/0000-0001-7513-7587

\section{Сведения об авторе}

Витторио Спрингфильд Томеллери, доктор филологических наук, профессор славянской филологии, Институт гуманитарных исследований государственного университета г. Мачерата, Via Illuminati 4, 62100 Macerata, Italia, vittorio.tomelleri@unimc.it, http://orcid.org/0000-0001-7513-7587 